San Jose State University

SJSU ScholarWorks

Master's Theses

Master's Theses and Graduate Research

Fall 2011

\title{
Halogenation Enzymes in Bacteria Associated with the Red- banded Acorn Worm, Ptychodera jamaicensis
}

Milena May Lilles

San Jose State University

Follow this and additional works at: https://scholarworks.sjsu.edu/etd_theses

\section{Recommended Citation}

Lilles, Milena May, "Halogenation Enzymes in Bacteria Associated with the Red-banded Acorn Worm, Ptychodera jamaicensis" (2011). Master's Theses. 4099.

DOI: https://doi.org/10.31979/etd.snbx-gv6x

https://scholarworks.sjsu.edu/etd_theses/4099

This Thesis is brought to you for free and open access by the Master's Theses and Graduate Research at SJSU ScholarWorks. It has been accepted for inclusion in Master's Theses by an authorized administrator of SJSU ScholarWorks. For more information, please contact scholarworks@sjsu.edu. 
HALOGENATION ENZYMES IN BACTERIA ASSOCIATED WITH THE REDBANDED ACORN WORM, PTYCHODERA JAMAICENSIS

\author{
A Thesis \\ Presented to \\ The Faculty of the Department of Biology \\ San José State University \\ In Partial Fulfillment \\ of the Requirements for the Degree \\ Master of Science
}

by

Milena M. Lilles

December 2011 
(C) 2011

Milena M. Lilles

ALL RIGHTS RESERVED 
The Designated Thesis Committee Approves the Thesis Titled

HALOGENATION ENZYMES IN BACTERIA ASSOCIATED WITH THE REDBANDED ACORN WORM, PTYCHODERA JAMAICENSIS

by

Milena M. Lilles

APPROVED FOR THE DEPARTMENT OF BIOLOGY

SAN JOSÉ STATE UNIVERSITY

December 2011
Dr. Sabine Rech
Department of Biology
Dr. Brandon White
Department of Biology
Dr. Roy Okuda
Department of Chemistry 


\title{
ABSTRACT \\ HALOGENATION ENZYMES IN BACTERIA ASSOCIATED WITH THE RED- BANDED ACORN WORM, PTYCHODERA JAMAICENSIS
}

\author{
by \\ Milena M. Lilles
}

Organohalogens have diverse biological functions in the environment. Marine acorn worms produce brominated products that may act as antifoulants, chemical deterrents, and substrates in bioluminescence reactions. Haloperoxidases purified from the homogenates of acorn worms synthesize bromophenols. Commensal or mutualistic bacteria living on the worms may produce halogenation enzymes that brominate organics.

The genomic DNA of 48 bacterial isolates from the surface of the red-banded acorn worm, Ptychodera jamaicensis, was extracted and screened for bromoperoxidase and $\mathrm{FADH}_{2}$-dependent halogenase genes. A $16 \mathrm{~S}$ rDNA phylogenetic tree showed that the isolates were gram-positive bacteria and included 36 Firmicutes and 12 Actinobacteria. Nineteen isolates had a 700 base-pair bromoperoxidase gene, and two isolates had a 1,000 base-pair $\mathrm{FADH}_{2}$-dependent halogenase gene.

Eight of the 19 isolates positive for the bromoperoxidase gene were tested for bromoperoxidase activity with a phenol red and monochlorodimedone assay. One isolate had the bromoperoxidase gene and bromoperoxidase activity of 0.417 in the monochlorodimedone assay. It is possible that bacteria on the red-banded acorn worm synthesize bromoperoxidases, which produce bromophenols. These bacteria may synthesize these compounds as antimicrobials towards gram-negative bacteria. 


\section{ACKNOWLEDGEMENTS}

This work was supported by: STEM Research Grant P031C080030, TriBeta Research Foundation Grant, and the SJSU Department of Biological Sciences Departmental Fellowship, 2009.

This project was possible with the hard work of several individuals:

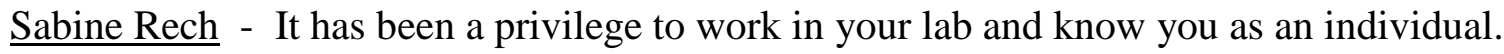
I am truly grateful for this opportunity. You have shown me how to be generous with my time in helping others. Thank you for the numerous theses proofreading sessions and allowing me the independence to explore my ideas.

Brandon White - Thank you for your help with the project, and for being a great molecular biology teacher!!

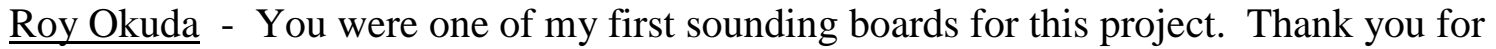
helping me to get my head around this project and for taking the time and talking with me about acorn worms and bromoperoxidases!

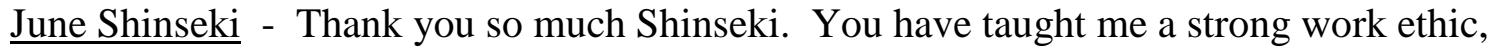
and I could not have finished this project without you. You are the true worker behind it, and I will always appreciate your friendship and time that you gave of yourself.

Misha Levish - Thank you so much for your time and care in the lab. I wouldn't be able to finish this project without the grant that you earned from TriBeta!! I think you are an amazing person and know that you will succeed in whatever you may do.

Mimi Ngo - Thank you Mimi for continuing to help on this project and finishing it off with us this fall and possibly spring semester... When we were tired from working on the protein isolates, you came in and brought fresh energy to the project!

Omar Garcia - You did so much in the lab in such a small amount of time. Thank you for your hard work over the summer and of course your poster presentation!

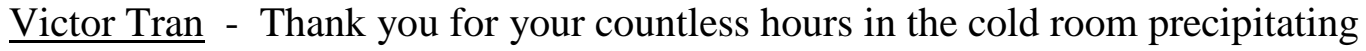
proteins, I am grateful to you. Thank you for keeping June and me laughing.

Elaine Bryant - Thank you for helping me get grounded in the beginning of my stay here at SJSU. I have learned so much from you and appreciate all your energy and contributions to this project!

Paula Matheus-Carnevali - Thank you Paula for your help with molecular techniques in the lab, and for our RUMBA 2009 teaching experience. 
The Environmental Microbiology Laboratory Assistants - Rawni Lunsford, Carlo Testa, Jen Albrecht, Mira Brahmbhatt, Justin Yee, and Andrew McFall. I have enjoyed getting to know each of you. I wish you all the best! Thank you for making the Environmental Lab so fun!

The SJSU Biological Sciences Support Staff - Art Valencia, Veronica Zavala, Matt Voisinet, and Tim Andriese. Thank you for all your help with supplies.

My dear family - Roger Lilles, I cannot put into words the unconditional support that you have given me on this project and in life. I wouldn't have been able to accomplish anything like this without you. I love you and thank you with all my heart.

Linda Lilles - Thank you for always supporting me to keep going.

Aimee Zeff and Alex Lilles - For being awesome siblings, and putting up with me. Craig Zeff - For listening to my countless stories. 


\section{TABLE OF CONTENTS}

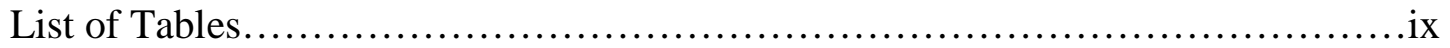

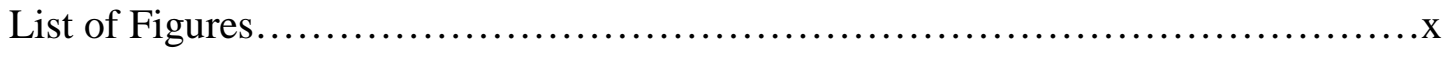

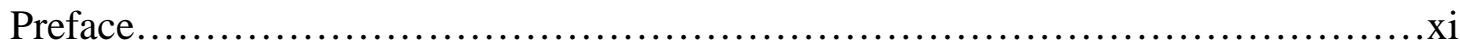

Chapter 1: Literature Review...................................................

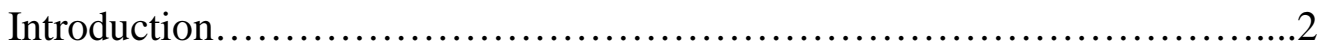

Heme Haloperoxidases...............................................

Vanadium Haloperoxidases...........................................11

Cofactor-free Haloperoxidases....................................... 16

FADH $_{2}$-dependent Halogenases...................................... 18

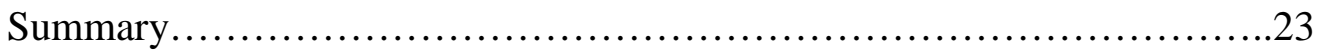

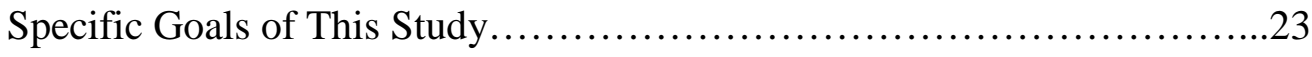

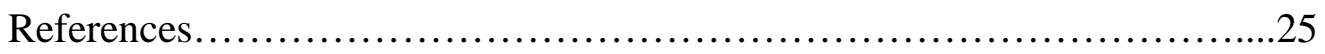

Chapter 2: Halogenation Enzymes in Bacteria Associated with the Red-Banded Acorn Worm, Ptychodera jamaicensis.........................................33

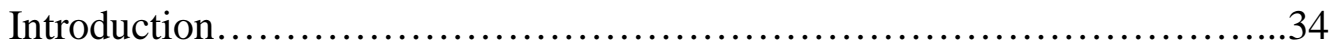

Experimental Procedures.................................................

16S rDNA Amplification, Sequencing, and Phylogenetic Analysis...37

Bromoperoxidase Amplification, Sequencing, and Phylogenetic

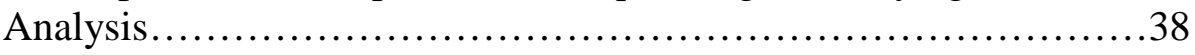

Bromoperoxidase Purification: Sonication, Ammonium Sulfate Precipitation, and Anion-exchange Chromatography..................40

PhastSystem $^{\mathrm{TM}}$ Separation of Proteins and Coomassie Staining.........42 
Phenol Red Gel Assay.......................................42

Monochlorodimedone Assay....................................43

Bacterial Growth Curve of Isolate I37..........................44

$\mathrm{FADH}_{2}$-Dependent Halogenase Amplification, Sequencing and Phylogenetic Analysis..........................................44

Results.....................................................46

16S rDNA Phylogenetic Tree.....................................46

Bromoperoxidase Genetic Analysis............................49

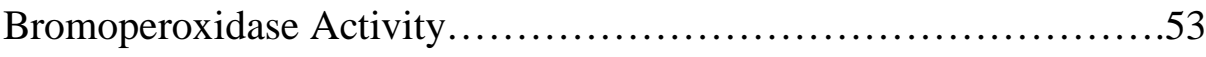

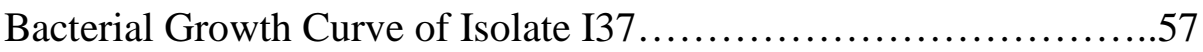

$\mathrm{FADH}_{2}$-Dependent Halogenase Genetic Analysis..................57

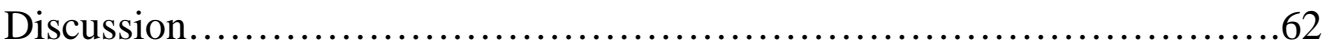

16S rDNA Phylogenetic Tree.................................62

Bromoperoxidase Genetic Analysis............................63

Bromoperoxidase Activity and Bacterial Growth Curve of Isolate

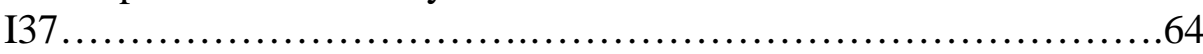

$\mathrm{FADH}_{2}$-Dependent Halogenase Genetic Analysis.................67

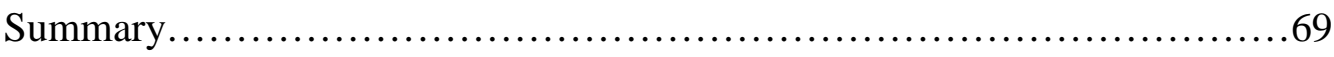

References..................................................... 72 


\section{LIST OF TABLES}

Table 1. Representative Heme Haloperoxidase Reactions.......................5

Table 2. Vanadium Haloperoxidase Reactions................................ 13

Table 3. Halogenation Reactions of Cofactor-Free Haloperoxidases...............17

Table 4. Representative $\mathrm{FADH}_{2}$-Dependent Halogenase Reactions................19

Table 5. Molecular Weights of Bromoperoxidases from Bacterial Isolates...........56 


\section{LIST OF FIGURES}

Figure 1. The Monochlorodimedone Assay $\ldots \ldots \ldots \ldots \ldots \ldots \ldots \ldots \ldots \ldots \ldots \ldots \ldots . \ldots$

Figure 2. The Phenol Red Assay..........................................43

Figure 3. 16S rDNA Neighbor-Joining Phylogenetic Tree of Bacterial Isolates.....48

Figure 4. Representative Positive Bromoperoxidase Gel Isolates..................51

Figure 5. Bromoperoxidase Gene Sequence Alignment Using ClustalW2 ..........52

Figure 6. Bromoperoxidase Neighbor-Joining Phylogenetic Tree.................53

Figure 7. Phenol Red Activity Gel (A) and Coomassie Blue Gel (B) of

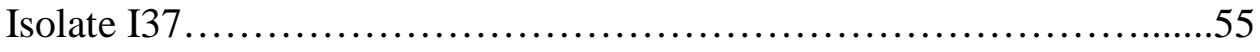

Figure 8. Phenol Red Activity Gel (A) and Coomassie Blue Gel (B) of

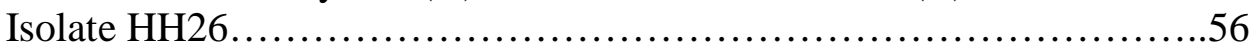

Figure 9. Bacterial Growth Curve of Isolate I37 ...........................57

Figure 10. $\mathrm{FADH}_{2}$-Dependent Halogenase from Isolate $\mathrm{X} 36 \ldots \ldots \ldots \ldots \ldots \ldots \ldots . \ldots . \ldots . \ldots . \ldots$

Figure 11. $\mathrm{FADH}_{2}$-Dependent Halogenase Alignment Using ClustalW2 ..........60

Figure 12. $\mathrm{FADH}_{2}$-Dependent Halogenase Neighbor-Joining Phylogenetic Tree....61 


\section{PREFACE}

The following thesis is presented as two journal articles. Chapter 1 is a literature review of research on haloperoxidase and $\mathrm{FADH}_{2}$-dependent halogenase enzymes and their organohalogen production. Chapter 2 presents research on cofactor-free bromoperoxidase and $\mathrm{FADH}_{2}$-dependent halogenase genes from bacteria associated with the red-banded acorn worm, Ptychodera jamaicensis. Bromoperoxidase activity from eight bacterial isolates with the cofactor-free bromoperoxidase gene was also examined. 


\title{
CHAPTER 1
}

\section{Literature Review}

Milena Lilles ${ }^{1}$, Sabine Rech ${ }^{1}$, Joseph B. White ${ }^{1}$, and Roy Okuda ${ }^{2}$

\author{
${ }^{1}$ From the Department of Biological Sciences, San Jose State University, \\ San Jose, CA 95192 \\ ${ }^{2}$ From the Department of Chemistry, San Jose State University, \\ San Jose, CA 95192
}

\author{
Correspondence to: \\ Milena Lilles \\ Department of Biological Sciences \\ One Washington $\mathrm{Sq}$ \\ San Jose, CA 95192 \\ E-mail: mlilles@yahoo.com \\ Date submitted: October 2011
}




\section{Introduction}

Organohalogens are diverse compounds produced through biotic and abiotic processes. Brominated compounds are prevalent in marine environments, while chlorinated compounds are widespread in terrestrial sources (1). Organohalogens have various biological functions, for instance, as pheromones, growth hormones $(2,3)$, antibiotics $(4,5)$, and chemical deterrents $(6,7)$. Two of the main enzyme families responsible for the production of these compounds are the haloperoxidases and reduced flavin adenine dinucleotide $\left(\mathrm{FADH}_{2}\right)$-dependent halogenases. Haloperoxidases produce the chlorinated antibiotic caldariomycin and antimicrobial brominated heptanones $(8,9)$. The $\mathrm{FADH}_{2}$-dependent halogenases generate many halogenated antibiotics, including 7chlorotetracycline, chloramphenicol, pyrrolnitrin, pyoluteorin, balhimycin, pyrroindomycin B, thienodolin, and clorobiocin (10-19). The isolation and characterization of these enzymes may assist with the discovery and development of new pharmaceuticals. They also have potential uses as catalysts in green chemistry processes. There are several different types of haloperoxidase enzymes. The enzymes are designated by the most electronegative halide they oxidize, and their cofactor requirement. The chloroperoxidases oxidize chloride, bromide, and iodide. The bromoperoxidases oxidize bromide and iodide, and iodoperoxidases oxidize iodide. The heme and vanadium haloperoxidases require the transition metals heme and vanadium as cofactors. The cofactor-free haloperoxidases or perhydrolase enzymes do not require any metal cofactor. The reaction mechanism of the heme and vanadium haloperoxidases differs from the cofactor-free haloperoxidases. The heme and vanadium haloperoxidases 
form oxidized halogen intermediates, mainly in the form of hypohalous acids, through the dismutation of hydrogen peroxide (20). The hypohalous acids can act as halogenating agents that leave the enzyme active site to halogenate a broad variety of electron rich organic substrates. The hypohalous acids can also stay within the active site of the enzyme and halogenate specific substrates (21). In addition, some vanadium haloperoxidases have specific substrates. Conversely, the cofactor-free haloperoxidases catalyze halogenations through the reversible formation of peracids from organic acids and hydrogen peroxide (22).

The $\mathrm{FADH}_{2}$-dependent halogenases are known for halogenating specific substrates selectively. In fact, $\mathrm{FADH}_{2}$-dependent halogenase genes are identified in most gene clusters coding for enzymes involved in the production of halogenated metabolites, including halogenated antibiotics and antitumor compounds (23). The halogenation reaction requires flavin adenine dinucleotide (FAD), nicotinamide adenine dinucleotide (NADH) or nicotinamide adenine dinucleotide phosphate (NADPH), a flavin reductase, halide ions, and oxygen. The reaction mechanism is dependent on oxygen and may result in the formation of flavin hydroperoxide. This intermediate could activate aromatic rings and form oxidized intermediates that halogenate substrates. The vanadium haloperoxidases and $\mathrm{FADH}_{2}$-dependent halogenases catalyze the production of most of the halogenated pharmaceuticals found in the environment. 


\section{Heme Haloperoxidases}

The heme haloperoxidases are ubiquitous. These enzymes are present in vertebrates, invertebrates, fungi, algae, protozoans, and bacteria (Table 1). The heme haloperoxidases require appropriate halides, hydrogen peroxide, and use a range of

organic substrates in the halogenation reaction. The mechanism involves the reduction of hydrogen peroxide to water, with the oxidation of the cofactor heme-Fe (III) to heme-Fe $(\mathrm{IV})=\mathrm{O}$. This oxidized cofactor reacts with a halide $(\mathrm{X})$ and proton $(\mathrm{H})$ to form the oxidized enzyme intermediate, heme-Fe (III)-OXH. The resulting hypohalous acid $(\mathrm{OXH})$ produced can break from the enzyme and freely halogenate substrates (24). It is unclear whether this is the principal reaction mechanism due to the difficulty of isolating specific halogenating agents. Hypohalous acids, elemental halogens, and halogen-ion intermediates can be used as halogenating agents. Representative heme haloperoxidases in animals, fungi, algae, and bacteria are described in Table 1. 
Table 1. Representative Heme Haloperoxidase Reactions.

\begin{tabular}{|c|c|c|}
\hline Enzyme \& Species & Substrate & Organohalogens \\
\hline \multicolumn{3}{|l|}{ Animals } \\
\hline $\begin{array}{l}\text { Myeloperoxidase } \\
\text { Homo sapiens }\end{array}$ & tyrosyl residues & $\begin{array}{l}\text { chlorotyrosine }(25) \\
\text { 3-chlorotyrosine }(26)\end{array}$ \\
\hline $\begin{array}{l}\text { Eosinophil peroxidase } \\
\text { Homo sapiens }\end{array}$ & tyrosyl residues & 3-bromotyrosine (26) \\
\hline $\begin{array}{l}\text { Thyroid peroxidase } \\
\text { Homo sapiens }\end{array}$ & $\begin{array}{l}\text { tyrosine, } \\
\text { Thyroglobulin }\end{array}$ & thyroxine (27) \\
\hline $\begin{array}{l}\text { Chloroperoxidase } \\
\text { Notomastus lobatus }\end{array}$ & phenol & $\begin{array}{l}\text { 4-bromophenol, 2,4-dibromophenol } \\
\text { 2,4,6-tribromophenol (28) }\end{array}$ \\
\hline \multicolumn{3}{|l|}{ Fungi } \\
\hline \multirow{3}{*}{$\begin{array}{l}\text { Chloroperoxidase } \\
\text { Caldariomycin fumago }\end{array}$} & $\beta$-ketoadipate & ठ-chlorolevulinic acid (29) \\
\hline & tyrosine & $\begin{array}{l}\text { mono and di (chloro, bromo, iodo) } \\
\text { tyrosines ( } 30)\end{array}$ \\
\hline & $\begin{array}{l}\text { 2-chloro-1, } \\
\text { 3-cyclo } \\
\text { pentanedione }\end{array}$ & $\begin{array}{l}\text { 2,2-dichloro-1, 3-cyclopentanedione } \\
\text { (8) }\end{array}$ \\
\hline \multicolumn{3}{|l|}{ Algae } \\
\hline $\begin{array}{l}\text { Bromoperoxidase } \\
\text { Bonnemaisonia } \\
\text { hamifera }\end{array}$ & $\begin{array}{l}\text { 3-oxooctanoic } \\
\text { acid }\end{array}$ & $\begin{array}{l}\text { dibromomethane } \\
\text { bromoform } \\
\text { 1-pentyl bromide (31) }\end{array}$ \\
\hline $\begin{array}{l}\text { Bromoperoxidase } \\
\text { Penicillus capitatus }\end{array}$ & $\begin{array}{l}\text { 3-oxooctanoic } \\
\text { acid }\end{array}$ & $\begin{array}{l}\text { 1-bromo-2-heptanone, } \\
\text { 1,1-di-bromo-2-heptanone, } \\
\text { 1,1,1-tribromo-2-heptanone (9) }\end{array}$ \\
\hline \multicolumn{3}{|l|}{ Bacteria } \\
\hline $\begin{array}{l}\text { Bromoperoxidase } \\
\text { Streptomyces } \\
\text { phaeochromogenes }\end{array}$ & pyrrolnitrin & 2-bromo-pyrrolnitrin (32) \\
\hline $\begin{array}{l}\text { Bromoperoxidase- } \\
\text { catalase } \\
\text { Streptomyces } \\
\text { venezuelae }\end{array}$ & $\begin{array}{l}\text { 1-methyl-2- } \\
\text { pyrrole }\end{array}$ & brominated 1-methyl-2-pyrrole (33) \\
\hline
\end{tabular}


Myeloperoxidase, eosinophil peroxidase and thyroid peroxidase are heme haloperoxidases in the human body that halogenate tyrosyl residues and tyrosine as common substrates. The end products of the myeloperoxidase and eosinophil peroxidase reactions are hypohalous acids, not organohalogens. Hypohalous acids have biocidal activity targeting microorganisms invading the immune system. Myeloperoxidase forms hypochlorous acid from the respiratory burst of neutrophils, while eosinophil peroxidase generates hypobromous acid during eosinophil degranulation. Both enzymes are capable of halogenating tyrosyl residues in proteins, but their primary purpose appears to be immune system support $(25,26)$. In contrast, thyroid peroxidase produces the predominant organohalogen of the human body, the thyroid hormone 3,5,3', ',tetraiodothyronine or thyroxine. Thyroid peroxidase oxidizes iodide to iodine, which halogenates tyrosine to generate thyroxine (27). Thyroxine is responsible for stimulating the consumption of oxygen in the body and increasing metabolism.

Marine acorn worms synthesize several types of volatile organohalogens. At least eleven species of hemichordate worms produce brominated and chlorinated compounds including bromophenols, bromopyrroles, bromo- and chloroindoles, bromohydroquinones, and bromo-cyclohexanes $(34,35)$. The first heme haloperoxidase isolated from a marine acorn worm was a chloroperoxidase from Notomastus lobatus. This chloroperoxidase catalyzes the bromination of phenol producing 4-bromophenol, 2,4-dibromophenol and 2,4,6-tribromophenol (28). These brominated phenols are naturally concentrated around the tail region of the worm. The chloroperoxidase accounts for about $0.7 \%$ of the total soluble protein in crude extracts and requires a 
flavoprotein for activity. Similar haloperoxidase activity in the homogenates of the marine invertebrates Thelepus setosus and Ptychodera flava laysanica catalyze the bromination of $p$-hydroxybenzyl alcohol (36).

The bromophenols from acorn worms may act as negative allelochemicals to other organisms and possibly as substrates in bioluminescent reactions. A common function of invertebrate organohalogen production is chemical defense (1). The noxious organohalogens are concentrated near the tail of the worms and at the opening of acorn worm burrows so that they are the first compounds encountered. Some of the halogenated products isolated from these worms are 3-haloindoles from the genera Ptychodera and Glossobalanus and bromophenols from the genus Balanoglossus (37). These organohalogens are responsible for the characteristic iodoform odor of the worms and negatively affect some non-organohalogen producing polychaetes and juvenile bivalves from settling close to contaminated burrows $(7,38)$. Although the halometabolites do not directly ward off predators, they appear to protect acorn worm settlements from encroaching organisms.

The worms belonging to the genera Ptychodera, Glossobalanus, and Balanoglossus have bioluminescent capabilities (39). A luciferin and luciferase isolated from Balanoglossus biminiensis extracts displayed a blue-green luminescence upon the addition of hydrogen peroxide (40). The purified luciferin had an iodoform odor, as does 2,6-dibromophenol, the primary halogenated product isolated from B. biminiensis (41). B. biminiensis may produce 2,6-dibromophenol as a luciferin in bioluminescence reactions. Luciferins are small molecules that are utilized by luciferase to produce energy 
in the form of light. The structure of the luciferin from B. bimineiensis has not been elucidated, but Cormier and Dure suggest that the luciferase is a peroxidase (40). More recently, a luminous compound 2,3,5,6- tetrabromohydroquinone (TBHQ), isolated from the acorn worm Ptychodera flava, displays green fluorescence when reacted with riboflavin, hydrogen peroxide, and horseradish peroxidase (42). Organohalogens and heme haloperoxidases may play a role in bioluminescent reactions.

The fungi produce many halogenated compounds of pharmaceutical interest (43). The first heme haloperoxidase isolated was from the fungus Caldariomyces fumago, and produces the chlorinated antibiotic caldariomycin. This extracellular chloroperoxidase chlorinates $\beta$-keto acids, cyclic $\beta$-diketones, tyrosine, and substituted phenols $(29,30)$. In particular, the chloroperoxidase chlorinates 1,3-cylcopentanedione and 2-chloro-1, 3cyclopentanedione to the caldariomycin intermediate, 2,2-dichloro-1, 3cyclopentanedione (8). This intermediate is reduced to caldariomycin by growing cultures of $C$. fumago. Based on the similarity in structure of 2,2-dichloro-1,3cyclopentanedione and 2-chloro-5,5-dimethyl-1,3-dimedone, or monochlorodimedone (MCD), a spectrophotometric haloperoxidase assay was developed to monitor the conversion of MCD to a dihalodimedone. The MCD assay follows the decrease in absorbance and subsequent disappearance of MCD in the enol form at a wavelength of $290 \mathrm{~nm}\left(€=20000 \mathrm{M}^{-1} \mathrm{~cm}^{-1}\right)$. This corresponds to the appearance of either bromochlorodimedone or dichlorodimedone, depending on the halide reactants (Fig. 1, 44). 

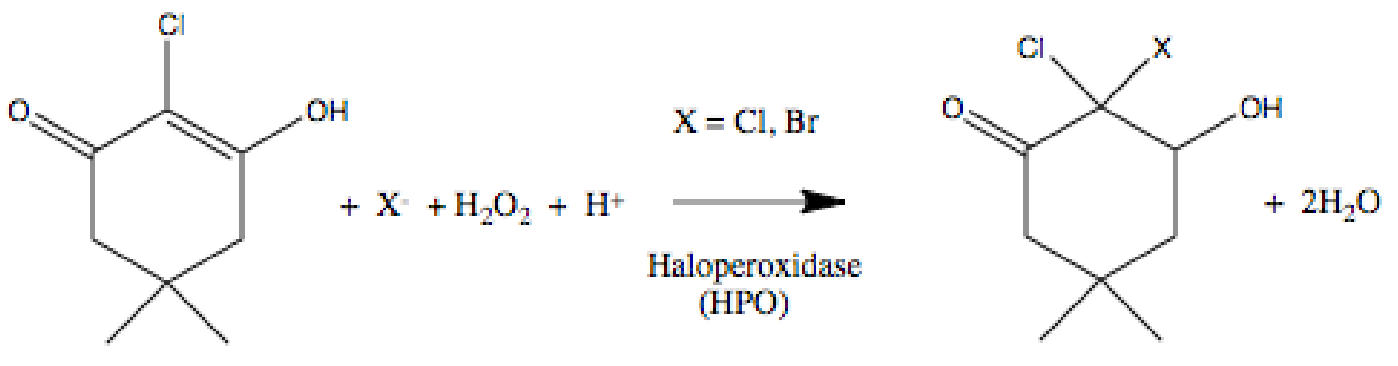

2-chloro-5,5-dimethyl-1,3-dimedone (monochlorodimedone)

Figure 1. The Monochlorodimedone Assay.

Marine algae synthesize halogenated organics with antifungal and antibacterial activity, possibly as antifoulants. The red algae are the largest organohalogen producers among marine algae. Red algae in the genera Bonnemaisonia and Asparagopsis, and the green alga Penicillus capitatus produce brominated heptanones. A heme bromoperoxidase isolated from Bonnemaisonia hamifera brominates 3-oxooctanoic acid to form bromomethane, bromoform and 1-pentyl bromide (31). In addition, a heme bromoperoxidase from the green alga Penicillus capitatus produces 1-bromo-2heptanone, 1,1-dibromo-2-heptanone, and 1,1,1-tribromo-2-heptanone from the bromination of 3-oxooctanoic acid (9). B. hamifera produces 1,1,3,3-tetrabromo-2heptanone, which has antifungal activity at a concentration of $100 \mu \mathrm{g} / \mathrm{ml}$ and antibacterial activity at higher concentrations (45). The crude extracts of B. hamifera inhibit nine out of eleven bacterial strains, including several gram-positive bacteria, a Bacteriodes bacterium, an alpha Proteobacterium, and four gamma Proteobacteria (46). However, brominated heptanones are not inhibitory toward E. coli LE392 or Pseudomonas putida KT2440 (46). These halogenated extracts reduce the microbial load on B. hamifera 
compared to other red algae. Many algae use organohalogens as antifouling agents. In particular, the Australian red macroalga Delisea pulchra produces brominated furanones that disrupt the growth of gram-negative biofilms. The brominated furanones inhibit gram-negative bacterial lactone signaling by preventing acyl lactones from binding with their receptors on nearby bacteria (47).

Most of the organohalogens that bacteria synthesize are antibiotics. However, heme haloperoxidases in bacteria show diverse catalytic activity and may play a more important role in hydrogen peroxide degradation. Bacterial heme haloperoxidases catalyze peroxidase and catalase reactions in addition to halogenation. This is also true of the heme chloroperoxidase from Caldariomyces fumago, which has peroxidase, catalase, and cytochrome P450 activity (48). The first isolated bacterial heme bromoperoxidase was from Streptomyces phaeochromogenes (32). A bromoperoxidasecatalase was later found in Streptomyces venezuelae ISP 5230. The bromoperoxidasecatalase has catalase, low peroxidase, and brominating activity (33). Both Streptomyces strains produce the chlorinated antibiotic chloramphenicol, but haloperoxidase genes were not found in the gene cluster coding for enzymes involved in the biosynthesis of chloramphenicol. Similarly, several bacteria in the Pseudomonas genus synthesize the chlorinated antibiotic pyrrolnitrin, but their heme haloperoxidases are not involved in its production, although some can halogenate pyrrole derivatives. The bromoperoxidase from Pseudomonas aureofaciens ATCC 15926 mutant strain ACN does not halogenate pyrrolnitrin, but does have catalase, peroxidase and brominating activity (49). In fact, the catalase negatively affects brominating activity by depleting available hydrogen peroxide 
in the reaction. Another pseudomonad with hydrogen peroxide degradation ability is from the Pseudomonad EF group 70B. It was found in recycled pulp process waters enriched with hydrogen peroxide (50). This bromoperoxidase-catalase has high catalase activity with halogenation as a side reaction.

There are some strains of Pseudomonas that have both heme and non-heme haloperoxidases. The bacterium Pseudomonas pyrrolnitrica has a heme containing catalase-bromoperoxidase and four non-heme bromoperoxidase isoenzymes (51). The non-heme haloperoxidases catalyze reactions including halogenations, oxidations, sulfoxidations, and epoxidations (52). Another pyrrolnitrin producer, Pseudomonas pyrrocina ATCC 15958, has a heme bromoperoxidase (53) and a non-heme chloroperoxidase (54). However, neither the heme nor the non-heme haloperoxidase is responsible for the halogenation of pyrrolnitrin $(55,13)$. The heme-haloperoxidases in the Streptomyces and Pseudomonas do not produce the chlorinated antibiotics chloramphenicol or pyrrolnitrin $(11,13,55)$.

\section{Vanadium Haloperoxidases}

The vanadium haloperoxidases are different from the heme haloperoxidases in that they require the transition metal vanadium and halides for the breakdown of hydrogen peroxide. In the heme haloperoxidase reaction, the heme cofactor is oxidized from the degradation of hydrogen peroxide (56), but in the vanadium haloperoxidase reaction the vanadium oxidation state does not change (57). However, vanadium haloperoxidases are inhibited by high concentrations of hydrogen peroxide (58). The 
most important difference between the heme and vanadium haloperoxidases is that some vanadium haloperoxidases can bind particular organic substrates and halogenate them in a regiospecific manner.

Most vanadium haloperoxidases are bromoperoxidases from marine algae, but some are also found in terrestrial fungi and marine bacteria. Vanadium bromoperoxidases are prominent in marine environments, where vanadium is the second most abundant transition metal (59), and bromide is present in high concentrations (1). Marine algae are promising sources of natural products because they manufacture heme and vanadium haloperoxidases and a wealth of halogenated metabolites. In the terrestrial environment, vanadium chloroperoxidases can be found in the fungi Curvularia inaequalis and Embellisia didymospora $(60,61)$. C. inaequalis is a pathogen of Zea mayes and may use vanadium chloroperoxidases to produce hypohalous acids and hydroxyl radicals that damage plant cell walls (62). These are the only peroxidases secreted by $C$. inaequalis. Representative vanadium haloperoxidase reactions from different organisms are outlined in Table 2. 
Table 2. Vanadium Haloperoxidase Reactions.

\begin{tabular}{|c|c|c|}
\hline Enzyme \& Species & Substrate & Organohalogens \\
\hline \multicolumn{3}{|l|}{ Algae } \\
\hline $\begin{array}{l}\text { Phaeophyceae } \\
\text { (Brown algae) } \\
\text { Bromoperoxidase } \\
\text { Fucus distichus, } \\
\text { Macrocystis pyrifera }\end{array}$ & $\begin{array}{l}\text { cytosine } \\
\text { taurine, Tris, Capso, } \\
\text { Tes, Hepes, Mops }\end{array}$ & $\begin{array}{l}\text { 5-bromocytosine } \\
\text { Br-taurine, Br-Tris, Br-Capso, } \\
\text { Br-Tes, Br-Hepes, Br-Mops (63) }\end{array}$ \\
\hline \begin{tabular}{|l|} 
Bromoperoxidase \\
Ascophyllum nodosum
\end{tabular} & $\begin{array}{l}\text { 2-methylindole } \\
\text { 2-phenylindole } \\
\text { phenol red }\end{array}$ & $\begin{array}{l}\text { 3-bromo-2-methylindole } \\
\text { 3-bromo-2-phenylindole } \\
\text { bromophenol blue (64) }\end{array}$ \\
\hline $\begin{array}{l}\text { Rhodophyceae } \\
\text { (Red algae) } \\
\text { Bromoperoxidase } \\
\text { Corallina officinalis, } \\
\text { Plocamium } \\
\text { cartilagineum, } \\
\text { Laurencia pacifica } \\
\end{array}$ & (E)-(+)-nerolidol & $\begin{array}{l}\alpha \text {-snyderol, } \beta \text {-snyderol, } \gamma \text { - } \\
\text { snyderol } \\
\text { (+)-3 } \beta \text {-bromo-8-epicaparrapi } \\
\text { oxide }(65)\end{array}$ \\
\hline $\begin{array}{l}\text { Bromoperoxidase } \\
\text { Corallina officinalis, } \\
\text { Plocamium } \\
\text { cartilagineum, } \\
\text { Laurencia pacifica }\end{array}$ & nerol & $\begin{array}{l}\text { 3-bromo-2,2,6-trimethyl-3,4,5,8- } \\
\text { tetrahydro2H-oxocine (66) }\end{array}$ \\
\hline \multicolumn{3}{|l|}{ Fungi } \\
\hline \begin{tabular}{|l|} 
Chloroperoxidase \\
Curvularia inaequalis, \\
Embellisia \\
didymospora \\
\end{tabular} & hydrogen peroxide & hypochlorous acid (62) \\
\hline \multicolumn{3}{|l|}{ Bacteria } \\
\hline $\begin{array}{l}\text { Chloroperoxidase } \\
\text { Streptomyces } \\
\text { aculeolatus NRRL } \\
18422 \\
\text { Streptomyces sp. } \\
\text { CNQ-525 }\end{array}$ & $\begin{array}{l}1,3,6,8- \\
\text { tetrahydroxynaphthalene }\end{array}$ & napyradiomycin (67) \\
\hline
\end{tabular}


The first vanadium haloperoxidase discovered was a vanadium bromoperoxidase from the brown marine alga, Ascophyllum nodosum. Competitive kinetic experiments and fluorescence quenching results show that the vanadium bromoperoxidase preferably brominates bound indole substrates (64). If indole is not bound, hypobromous acid can diffuse from the active site to halogenate unbound substrates. In addition to hypobromous acid, other oxidized vanadium bromoperoxidase intermediates are bromine, tribromide, and an enzyme bound "bromonium ion equivalent" (63). All these intermediates can act as halogenating agents. The vanadium bromoperoxidase from $A$. nodosum is one of the first characterized haloperoxidases that binds 2-methylindole and 2-phenylindole substrates, and halogenates them specifically to 3-bromo-2-methylindole and 3-bromo-2-phenylindole (Table 2, 64). Another brown alga, Laminaria digitata has both a vanadium bromoperoxidase and iodoperoxidase, and is one of the greatest iodine bioaccumulators of all living organisms (68). The bromoperoxidase catalyzes the bromination of monochlorodimedone and the iodoperoxidase converts iodide to triiodide. The iodine content in L. digitata is $1 \%$ of its dry weight, which is approximately a 30,000-fold accrual of iodine from seawater (69). The storage of iodine may aid in ultraviolet protection and as an antifouling agent. Haloperoxidases from L. digitata can also generate hypobromous acids that deactivate 3-oxo-acyl homoserine lactones involved in Pseudomonas aeruginosa biofilm formation and dispersal (70). The hypohalous acids and halogenated products from algae have antibacterial and antifouling abilities. 
The red marine algae Corallina officinalis, Plocamium cartilagineum, and Laurencia pacifica produce chiral brominated sesquiterpenes that act as precursors to natural products. These algae use vanadium bromoperoxidases to catalyze the enantiospecific bromination of sesquiterpenes through bromonium-ion induced cyclization $(65,66)$. The nerolidol and vanadium bromoperoxidase reaction synthesizes single diastereomers of $\beta$-snyderol and $\gamma$-snyderol (Table 2). The compounds $\alpha$-snyderol, $\beta$-snyderol, and laurencin are naturally produced by select red algae. Laurencin is very similar in structure to the monobromocyclic ether synthesized from the reaction of nerol and vanadium bromoperoxidase (66, Table 2$)$. The vanadium haloperoxidases in these red algae synthesize brominated sesquiterpenes with anti-plasmoidal and cytotoxic activity.

In bacteria, vanadium haloperoxidases may catalyze the synthesis of halogenated antibiotics. The napyradiomycin gene cluster from Streptomyces sp. CNQ-525 was heterologously expressed in Streptomyces albus and seven napyradiomycins were produced (67). Napyradiomycins are dihydroquinone antibiotics. Analyses of genes in the napyradiomycin pathway show three putative vanadium chloroperoxidase genes in Streptomyces aculeolatus NRRL 18422 and the marine bacterium Streptomyces sp. CNQ525 (67). The vanadium chloroperoxidases produced from these genes may cause the chloronium-induced cyclization of two terpene units in the meroterpenoid napyradiomycin biosynthetic pathway. Bromonium and chloronium-induced cyclization seems to be a common mechanism for the production of enantiospecific halogenated compounds among vanadium haloperoxidases in marine algae and bacteria. A vanadium 
bromoperoxidase gene was found in the cyanobacterium Synechococcus CC9311 (71). This is the first documentation of a bromoperoxidase gene and activity in free-living unicellular cyanobacteria (72). The vanadium bromoperoxidase sequenced from Synechococcus CC9311 is similar to vanadium bromoperoxidases in red algae and homologous to bromoperoxidases in the marine bacteria Acaryochloris marina, Synechococcus sp. PCC7335, and Crocosphaera watsonii. The vanadium bromoperoxidase gene appears to be within a cluster of horizontally transferred genes that may be from red algae (72). A. marina is a common epiphyte of red algae that may have acquired the bromoperoxidase from red algae, and transferred it to other photoautotrophic bacteria. The vanadium bromoperoxidase halogenates monochlorodimedone, but is not thought to have a specific organic substrate. Although brominated compounds have not been isolated from this bacterium, cyanobacteria do produce halogenated metabolites. Oscillatoria spongeliae lives as an endosmybiont in the marine sponge Dysidea herbacea and produces polybrominated biphenyl ethers (73). Genome mining research may find more vanadium haloperoxidases and halogenated products present in marine bacteria.

\section{Cofactor-Free Haloperoxidases (Perhydrolases)}

The cofactor-free haloperoxidases are perhydrolase enzymes that use organic acids such as acetate, propionate, or benzoate for halogenation. These enzymes do not break down hydrogen peroxide and thus are not true peroxidases. The perhydrolases have the same catalytic triad as serine hydrolases (Ser-Asp-His) and belong to the large 
and diverse alpha/beta $(\alpha / \beta)$ hydrolase fold enzyme class (74). The nucleophilic serine is typically found in the consensus sequence Gly-X-Ser-X-Gly (75). Perhydrolases catalyze halogenation reactions through the reversible formation of peracids (22). The peracids oxidize halides, which then halogenate organic substrates unspecifically.

The perhydrolase reaction mechanism is based on the serine residue of the active site attacking the carboxyl carbon of an organic acid and forming an acyl-enzyme. In the case of acetic acid, this bond is subsequently hydrolyzed by hydrogen peroxide to generate peracetic acid (76). The peracetic acid reacts with halides transported to the active site, forming hypohalous acids and other intermediates. The hydrophobic environment of the active site seems to protect the peracid against hydrolysis (76). There does not appear to be a binding site on the enzyme for halides, hypohalous acids, or specific substrates. These perhydrolases are not responsible for the synthesis of natural halogenated products, but do halogenate monochlorodimedone and other suitable substrates (Table 3).

Table 3. Halogenation Reactions of Cofactor-Free Haloperoxidases.

\begin{tabular}{|l|l|l|}
\hline Enzyme \& Species & Substrate & Organohalogens \\
\hline Bacteria & & \\
\hline $\begin{array}{l}\text { Chloroperoxidase } \\
\text { Streptomyces lividans } \\
\text { TK64 }\end{array}$ & indole & Monochloroindole (77) \\
\hline $\begin{array}{l}\text { Chloroperoxidase } \\
\text { Pseudomonas } \\
\text { pyrrocinia } \\
\text { ATCC 15958 }\end{array}$ & $\begin{array}{l}\text { indole } \\
\text { 4-(2-amino-3- } \\
\text { chlorophenyl) pyrrole }\end{array}$ & $\begin{array}{l}\text { 7-chloroindole (54) } \\
\text { Aminopyrrolnitrin (78) }\end{array}$ \\
\hline
\end{tabular}


The cofactor-free haloperoxidases are primarily found in bacteria, mainly from the genera Pseudomonas and Streptomyces (51, 54, 77-79). However, the nocardioform actinomycete, Rhodococcus erythropolis induces a non-heme haloperoxidase during the biodegradation of thiocarbamate herbicides (80). The enteric bacterium Serratia marcescens also synthesizes a non-heme chloroperoxidase that hydrolyzes carboxylic acids, oxidizes amines to nitro compounds, and has phosphatase activity $(81,82)$. The catalytic triad of perhydrolases is essential to the diversity of reactions that these enzymes can perform. It acts on various substrates in different biological contexts and can hydrolyze carboxylic acid esters, lipids, thioesters, peptides, epoxides, haloperoxides, and dehalogenases $(75,83)$. Although the perhydrolases are not true haloperoxidases, they can perform halogenation reactions if an appropriate organic acid is present.

\section{FADH $_{2}$-Dependent Halogenases}

As the name implies, the $\mathrm{FADH}_{2}$-dependent halogenases require a reductase to generate $\mathrm{FADH}_{2}$ from FAD and NADH or NADPH. The flavin co-substrate binds to a specific nucleotide site near the amino terminal $(\mathrm{GxGxxG})$ of the enzyme (84). Some halogenases have a second conserved motif near the middle of the enzyme for two tryptophan residues (WxWxIP). These conserved residues reflect the enzyme's substrate specificity for tryptophan and indole derivatives. The halogenation of tryptophan at the $\mathrm{C} 7$ position is the first reaction in the biosynthesis of the antibiotic pyrrolnitrin and the antitumor compound rebeccamycin $(12,85$, Table 4$)$. Other halogenases preferentially 
bind phenol and pyrrole derivatives. Several tryptophan halogenase reactions are illustrated in Table 4.

Table 4. Representative $\mathrm{FADH}_{2}$-Dependent Halogenase Reactions.

\begin{tabular}{|l|l|l|}
\hline Enzyme \& Species & Substrate & Organohalogens \\
\hline Protista & & \\
\hline $\begin{array}{l}\text { Flavin-dependent halogenase } \\
\text { (chlA) } \\
\text { Dictyostelium discoideum }\end{array}$ & $\begin{array}{l}\text { 2,4,6-trihydroxyphenyl- } \\
\text { 1-hexa-1-one (THPH) }\end{array}$ & dichloro-THPH (86) \\
\hline Bacteria & & \\
\hline $\begin{array}{l}\text { Tryptophan 7-halogenase } \\
\text { (prnA) } \\
\text { Pseudomonas fluorescens } \\
\text { BL915 }\end{array}$ & tryptophan & $\begin{array}{l}\text { 7-chlorotryptophan } \\
\text { (12) }\end{array}$ \\
\hline $\begin{array}{l}\text { Monodechloraminopyrrolnitrin } \\
\text { halogenase } \\
\text { (prnC) } \\
\text { Pseudomonas fluorescens } \\
\text { BL915 }\end{array}$ & pyrrolnitrin & \\
\hline $\begin{array}{l}\text { Tryptophan 7-halogenase } \\
\text { (rebH) } \\
\text { Lechevalieria aerocolonigenes } \\
\text { str. 39243 }\end{array}$ & tryptophan & $\begin{array}{l}\text { aminopyrrolnitrin } \\
\text { (13) }\end{array}$ \\
\hline $\begin{array}{l}\text { Tryptophan 5-halogenase } \\
\text { pyrH) }\end{array}$ & tryptophan & $\begin{array}{l}\text { 7-chlorotryptophan } \\
\text { Streptomyces rugosporus LL- } \\
\text { 42D005 }\end{array}$ \\
\hline $\begin{array}{l}\text { Tryptophan 6-halogenase } \\
\text { thal) } \\
\text { Streptomyces albogriseolus } \\
\text { MJ286-76F7 }\end{array}$ & tryptophan \\
\hline
\end{tabular}

Although the regioselective halogenation mechanism of $\mathrm{FADH}_{2}$-dependent halogenases is not fully understood, the dependence on oxygen in the reaction may result in the formation of flavin hydroperoxide. The hydroperoxide could activate aromatic rings by forming an epoxide, which when attacked by halide ions can generate 
regiospecific compounds, such as halohydrins (12). The flavin hydroperoxide could also form reactive $\mathrm{FAD}-\mathrm{O}-\mathrm{Cl}$ or hypohalous acid intermediates that halogenate substrates in a specific manner within the active site (20-21, 85). Regardless of the exact mechanism, the $\mathrm{FADH}_{2}$-dependent halogenases produce many halogenated antibiotics and a chlorinated differentiation factor (Table 4). Until 1997, haloperoxidase enzymes were thought to be the main halogenating enzymes, but $\mathrm{FADH}_{2}$-dependent halogenases synthesize many more halogenated antibiotics in bacteria than other halogenation enzymes $(84,87)$.

The $\mathrm{FADH}_{2}$-dependent halogenases produce several halogenated antibiotics and a growth hormone and are predicted to generate halogenated antifungal and antitumor compounds. These enzymes generate the halogenated antibiotics 7-chlorotetracycline, chloramphenicol, pyrrolnitrin, pyoluteorin, balhimycin, pyrroindomycin B, thienodolin, and clorobiocin (10-19). Though haloperoxidases are found in bacteria that produce the antibiotics pyrrolnitrin and chloramphenicol, they do not catalyze halogenation of these compounds $(55,13)$. The $p r n A$ and $p r n C$ genes in the pyrrolnitrin biosynthetic gene cluster of Pseudomonas fluorescens show similarity to $\mathrm{FADH}_{2}$-dependent halogenases and not haloperoxidases. Furthermore, $\mathrm{FADH}_{2}$-dependent halogenases encoded by the gene $\mathrm{cm} l \mathrm{~S}$ and adenylation enzymes encoded by the gene $\mathrm{cmlK}$ are responsible for the biosynthesis of the dichloroacetyl component of chloramphenicol in Streptomyces venezuelae ISP5230 (11). Therefore, it is evident that $\mathrm{FADH}_{2}$-dependent halogenases instead of haloperoxidases are responsible for the synthesis of halogenated antibiotics in these bacteria. 
Two $\mathrm{FADH}_{2}$-dependent halogenase genes are also found in the antifungal and antimicrobial kutznerides gene cluster isolated from soil actinomycetes (88). Kutznerides are cyclic depsipeptides consisting of six nonproteinogenic residues, including a chlorinated piperazic acid (88). One $\mathrm{FADH}_{2}$-dependent halogenase appears to be involved in the formation of 6,7-dichlorohexahydropyrroloindole and another in the chlorination of the piperazate unit. The gene cluster was constructed from degenerate primer-based PCR amplification of highly conserved mononuclear non-heme iron and $\mathrm{FADH}_{2}$-dependent halogenase genes in Kutzneria sp. 744. This gene cluster encodes six nonribosomal peptide synthetase (NRPS) modules, which are often responsible for the production of important pharmaceuticals. In NRPS modules, there are usually three functional domains consisting of an adenylation domain, a peptidyl carrier protein domain, and a condensation domain (89).

A FADH ${ }_{2}$-dependent halogenase in the amoeba Dictyostelium discoideum produces a halogenated compound for differentiated expression. This chlorinated differentiation-inducing factor (DIF-1) transforms amoeba cells into stalk cells by activating the expression of prestalk genes $(3,90)$. From enzymatic activity in vitro, researchers deduced that a heme chloroperoxidase twice chlorinates the polyketide precursor 2,4,6-trihydroxyphenyl-1-hexa-1-one (THPH) to form dichloro-THPH. Subsequently, the dichloro-THPH is methylated to form DIF-1 (90). The chlorination of THPH was based on chloroperoxidase activity and not supported with genetic evidence. Recently, the chlorinating gene was found to be $c h l A$, a $\mathrm{FADH}_{2}$-dependent halogenase. RT-PCR analysis reveals that the halogenase is up-regulated along with genes encoding a 
polyketide synthase $s t l B$ and methylation enzyme $d m t A$ (86). The polyketide synthase is involved in THPH formation. The halogenase was overexpressed in D. discoideum and upon reaction with THPH, the halogenase formed $\mathrm{Cl}-\mathrm{THPH}$, which was confirmed with liquid chromatography-mass spectrometry (86). In vivo experiments show that $\mathrm{FADH}_{2^{-}}$ dependent halogenase knockout mutants of D. discoideum had a deficiency in DIF-1, which led to collapsed fruiting bodies. This is the first example of a $\mathrm{FADH}_{2}$-dependent halogenase in a eukaryote combined with an organohalogen acting as a transcriptional activator. Other organisms may use organohalogens as growth hormones.

$\mathrm{FADH}_{2}$-dependent halogenases are proposed to synthesize the halogenated antitumor compounds rebeccamycin and neocarzilin in bacteria. Rebeccamyin has two chlorinated indole rings and is an indolocarbazole antitumor agent that functions as a weak topoisomerase I inhibitor (85). Two genes in the rebeccamycin gene cluster are predicted to code for a flavin reductase $(r e b F)$ and $\mathrm{FADH}_{2}$-dependent halogenase $(r e b H)$. These genes from L. aerocolonigenes were overexpressed in E.coli and produced reductase and halogenases that halogenate tryptophan in the first reaction of rebecaamycin synthesis. The neocarzilin antitumor compounds are aliphatic halometabolites characterized by their chloromethyl groups (91). The bacterium Streptomyces carzinostaticus var. F-41 has 14 open reading frames (ORFs) involved in the synthesis of neocarzilin. The chlorination step is likely from the product of ORF3, which encodes a $\mathrm{FADH}_{2}$-dependent halogenase, while ORF8 codes for a flavin reductase gene. The $\mathrm{FADH}_{2}$-dependent halogenases are involved in the production of many antimicrobial products and some antitumor compounds in bacteria. 


\section{Summary}

Many organisms produce haloperoxidases and $\mathrm{FADH}_{2}$-dependent halogenases that are involved in the formation of organohalogens. The hypohalous acids produced in these reactions act as halogenating agents when appropriate organic substrates are present. Hypohalous acids are also used as biocidal agents. The vanadium bromoperoxidases of marine algae synthesize brominated organics with antibacterial, antifouling, and cytotoxic activity $(9,45-47,65-66)$. But it is the $\mathrm{FADH}_{2}$-dependent halogenases that are the primary producers of halogenated antibiotics and antitumor compounds in bacteria (Table 4). Recently, however, vanadium chloroperoxidases and bromoperoxidases were found in two bacterial strains $(67,72)$. In fact, Pseudomonas and Streptomyces produce heme and non-heme haloperoxidases, vanadium haloperoxidases, and $\mathrm{FADH}_{2}$-dependent halogenases. More bacteria should be screened for halogenation enzymes. These enzymes are beneficial in green-chemical processes, and new pharmaceutical compounds may be discovered.

\section{Specific Goals of This Study}

Marine acorn worms are shell-less organisms that produce halogenated organics, mainly bromophenols. Organohalogens are common chemical defenses found in species that do not have a hard outer shell or other physical protection against predators. Acorn worms may bioaccumulate microorganisms in the sand for the production of organohalogens. Symbiotic bacteria living with marine acorn worms may produce halogenation enzymes that have the capacity to brominate phenolic compounds. To test 
this idea, bacteria were isolated from the slime associated with the red-banded acorn worm Ptychodera jamaicensis. The goal of this research was to characterize the marine bacteria present on the red-banded acorn worm Ptychodera jamaicensis and screen for halogenation genes and enzyme activity. This research will help to increase our understanding of acorn worm organohalogen production. The following genes and enzymes were assayed:

1. the $16 \mathrm{~S}$ rDNA gene in each bacterial isolate to characterize the bacteria present on the worm,

2. bromoperoxidase and $\mathrm{FADH}_{2}$-dependent halogenase genes, 3. bromoperoxidase enzyme activity in partially purified protein fractions. 


\section{References}

1. Gribble, G.W. (2004) American Scientist 92, 342-349

2. Sonenshine, D.E., Silverstein, R.M., Plummer, E., West, J.R., and McCullough, T. (1976) J. Chem. Ecol. 2, 201-209

3. Kay, R. R. (1998) J. Biol. Chem. 273, 2669-2675

4. Hardt, I.H., Jensen, P.R., and Fenical W. (2000) Tetrahedron Lett. 41, 20732076

5. Oh, K., Lee, J.H, Chung, S., Shin, J., Shin, H.J., Kim, H., and Lee, H. (2008) Bioorg. Med. Chem. Lett. 18, 104-108

6. Pawlik, J.R. (1993) Chem. Rev. 93, 1911-1922

7. Woodin, S.A., Marinelli, R.L., and Lincoln, D.E. (1993) J. Chem. Ecol. 19, 517-530

8. Beckwith, J.R., and Hager, L.P. (1963) J. Biol. Chem. 238, 3091-3094

9. Beissner, R.S., Guilford, W.J., Coates, R.M., and Hager, L.P. (1981) Biochemistry 20, 3724-3731

10. Dairi, T., Nakano, T., Aisaka, K., Katsumata, R., and Hasegawa, M. (1995) Biosci., Biotechnol., Biochem. 59, 1099-1106

11. Piraee, M., White, R.L., and Vining, L.C. (2004) Microbiology 150, 85-94

12. Hammer, P.E., Hill, D.S., Lam, S.T., van Pée, K.H., and Ligon, J.M. (1997) Appl. Environ. Microbiol. 63, 2147-2154 
13. Keller, S., Wage, T., Hohaus, K., Hölzer, M., Eichhorn, E., and van Pée, K.H. (2000) Angew. Chem., Int. Ed. 39, 2300-2302

14. Hohaus, K., Altmann, A., Burd, W., Fischer, I., Hammer, P.E., Hill, D.S., Ligon, J.M., and van Pée, K.H. (1997) Angew. Chem. Int. Ed. Engl. 36, 2012-2013

15. Nowak-Thompson, B., Chaney, N., Wing, J.S., Gould, S.J., and Loper, J.E. (1999) J. Bacteriol. 181, 2166-2174

16. Pelzer, S., Süßmuth, R., Heckmann, D., Recktenwald, J., Huber, P., Jung, G., and Wohlleben, W. (1999) Antimicrob. Agents Chemother. 43, 15651573

17. Zehner, S., Kotzsch, A., Bister, B., Süssmuth, R.D., Méndez, C., Salas, J.A., and van Pée, K.H. (2005) Chem. Biol. 12, 445-452

18. Seibold, C., Schnerr, H., Rumpf, J., Kunzendorf, A., Hatscher, C., Wage, T., Ernyei, A.J., Dong, C., Naismith, J.H., and van Pée, K.H. (2006) Biocatal. Biotransform. 24, 401-408

19. Eustáquio, A., Gust, B., Luft, T., Li, S., Chater, K.F., and Heide, L. (2003) Chem. Biol. 10, 279-288

20. Fujimori, D.G, and Walsh, C. (2007) Curr. Opin. Chem. Biol. 11, 553-560

21. Blasiak, L.C., and Drennan, C.L. (2008) Acc. Chem. Res. 42, 147-155

22. Bernhardt, P., Hult, K., and Kazlauskas, R.J. (2005) Angew. Chem. 44, 2742-2746

23. van Pée, K.H., and Unversucht, S. (2003) Chemosphere 52, 299-312 
24. Murphy, C.D. (2003) J. Appl. Micr. 94, 539-548

25. Domigan, N.M., Charlton, T.S., Duncan, M.W., Winterbourn, C.C., and Kettle, A.J. (1995) J. Biol. Chem. 270, 16542-16548

26. Aldridge, R.E., Chan, T., van Dalen, C.J., Senthilmohan, R., Winn, M., Venge, P., Town, G.I., and Kettle, A.J. (2002) Free Radical Biol. Med. 33, $847-856$

27. Taurog, A., and Howells, E.M. (1966) J. Biol. Chem. 6, 1329-1339

28. Chen, Y.P., Lincoln, D.E., Woodin, S.A., and Lovell C.R. (1991) J. Biol. Chem. 266, 23909-23915

29. Beckwith, J.R., Clark, R., and Hager, L.P. (1963) J. Biol. Chem. 238, 30863090

30. Hager, L.P., Morris, D.R., Brown, F.S., and Eberwein H. (1966) J. Biol. Chem. 241, 1769-1777

31. Theiler, R., Cook, J.C., Hager, L.P., and Siuda, J.F. (1978) Science 202, 1094-1096

32. van Pée, K.H., and Lingens, F. (1984) FEBS Lett. 173, 5-8

33. Knoch, M., van Pée, K.H., Vining, L.C., and Lingens, F. (1989) J. Gen. Microbiol. 135, 2493-2502

34. Higa, T., and Scheuer, P.J. (1977) Mar. Nat. Prod. Chem. 35, 35-43

35. Fielman, K.T., and Targett, N.M. (1995) Mar. Ecol. Prog. Ser. 116, 125-136 
36. Ahern, T.J., Allan, G.G., and Medcalf, D.G. (1980) Biochim. Biophys. Acta, Enzymology 616, 329-339

37. Higa, T., Fugiyama, T., and Scheuer, P.J. (1980) Comp. Biochem. Physiol., Part B: Biochem. Mol. Biol. 65, 525-530

38. Woodin, S.A., Lindsay, S.M., and Lincoln, D.E. (1997) Mar. Ecol. Prog. Ser. 157, 303-306

39. Shimomura, O. (2006) Bioluminescence: Chemical Principles and Methods, World Scientific Publishing Co. Pte. Ltd., Hackensack, NJ

40. Cormier, M.J., and Dure, L.S. (1963) J. Biol. Chem. 238, 785-789

41. Ashworth, R.B., and Cormier, M.J. (1967) Science 155, 1558-1559

42. Kanakubo, A., Koga, K., Isobe, M., and Yoza, K. (2005) Luminescence 20, $397-400$

43. Dembitsky, V.M., and Tolstikov, G.A. (2003) Chemistry for Sustainable Development 11, 557-565

44. Neidleman, S.L., and Geigert, J. (1986) Biohalogenation:Principles, basic roles, and applications John Wiley \& Sons, Hoboken, NJ

45. Siuda, J.F., Van Blaricom, G.R., Shaw, P.D., Johnson, R.D., White, R.H., Hager, L.P., and Rinehart, K.L., Jr. (1975) J. Am. Chem. Soc. 97, 937-938

46. Nylund, G.M., Cervin, G., Hermansson, M., and Pavia, H. (2005) Mar. Ecol. Prog. Ser. 302, 27-36 
47. Manefield, M., de Nys, R., Kumar, N., Read, R., Givskov, M., Steinberg, P., and Kjelleberg, S. (1999) Microbiology 145, 283-291

48. Sundaramoorthy, M., Terner, J., and Poulos, T.L. (1995) Structure 3, $1367-1377$

49. van Pée, K.H., and Lingens, F. (1985) J. Bacteriol. 161, 1171-1175

50. Kuusk, H., Björklund, M., and Rydström, J. (2001) Enzyme Microb. Technol. 28, 617-624

51. Itoh, N., Morinaga, N., and Nomura, A. (1992) Biochim. Biophys. Acta, Proteins and Molecular 1122, 189-195

52. Dembitsky, V.M. (2003) Tetrahedron 59, 4701-4720

53. Wiesner, W., van Pée, K.H., and Lingens, F. (1985) Biol. Chem., Hop.-Sey. 366, 1085-1091

54. Wiesner, W., van Pée, K.H., and Lingens, F. (1986) FEBS Lett. 209, 321324

55. Kirner, S., Hammer, P.E., Hill, D.S., Altmann, A., Fischer, I., Weislo, L.J., Lanahan, M., van Pée, K.H., and Ligon, J.M. (1998) J. Bacteriol. 180, 1939-1943

56. Soedjak, H.S., and Butler, A. (1990) Biochemistry 29, 7974-7981

57. Winter, J.M., and Moore, B.S. (2009) J. Biol. Chem. 284, 18577-18581

58. Soedjak, H.S., Walker, J.V., and Butler, A. (1995) Biochemistry 34, 1268912696 
59. Butler, A., and Carter-Franklin, J.N. (2004) Nat. Prod. Rep. 21, 180-188

60. van Schijndel, J.W.P.M, Vollenbroek, E.G.M., and Wever, R. (1993)

Biochim. Biophys. Acta, Protein Structure and Molecular Enzymology 1161, 249-256

61. Barnett, P., Hemrika, W., Dekker, H.L., Muijsers, A.O., Renirie, R., and Wever, R. (1998) J. Biol. Chem. 273, 23381-23387

62. Barnett, P., Kruitbosch, D.L., Hemrika, W., Dekker, H.L., and Wever, R. (1997) Biochim. Biophys. Acta, Gene Regul. Mech. 1352, 73-84

63. Butler, A., and Walker, J.V. (1993) Chem. Rev. 93, 1937-1944

64. Tschirret-Guth, R.A., and Butler, A. (1994) J. Am. Chem. Soc. 116, 411412

65. Carter-Franklin, J.N., and Butler, A. (2004) J. Am. Chem. Soc. 126, 1506015066

66. Carter-Franklin, J.N., Parrish, J.D., Tschirret-Guth, R.A., Little, R.D., and Butler, A. (2003) J. Am. Chem. Soc. 125, 3688-3689

67. Winter, J.M., Moffitt, M.C., Zazopoulos, E., McAlpine, J.B., Dorrestein, P.C., and Moore, B.S. (2007) J. Biol. Chem. 282, 16362-16368

68. Colin, C., Leblanc, C., Wagner, E., Delage, L., Leize-Wagner, E., Van Dorsselaer, A., Kloareg, B., and Potin, P. (2003) J. Biol. Chem. 278, 23545-23552

69. Gall, E.A., Küpper, F.C., and Kloareg, B. (2004) Botanica Marina 47, 3037 
70. Borchardt, S.A., Allain, E.J., Michels, J.J., Stearns, G.W., Kelly, R.F. and McCoy, W.F. (2001) Appl. Environ. Microbiol. 67, 3174-3179

71. Palenik, B., Ren, Q., Dupont, C.L., Myers, G.S., Heidelberg, J.F., Badger, J.H., Madupu, R., Nelson, W.C., Brinkac, L.M., Dodson, R.J., Durkin, A.S., Daugherty, S.C., Sullivan, S.A., Khouri, H., Mohamoud, Y., Halpin, R., and Paulsen, I.T. (2006) Proc. Natl. Acad. Sci. U.S.A. 36, 13555-13559

72. Johnson, T.L., Palenik, B., and Brahamsha, B. (2011) J. Phycol. 47, 792801

73. Unson, M.D., Holland, N.D., and Faulkner, D.J. (1994) Mar. Biol. 119, 111

74. Pelletier, I., Altenbuchner, J, and Mattes, R. (1995) Biochim. Biophys. Acta 1250, 149-157

75. Holmquist, M. (2000) Curr. Protein Pept. Sci. 1, 209-235

76. Hofmann, B., Tölzer, S., Pelletier, I., Altenbuchner, J., van Pée, K.H., and Hecht, H.J. (1998) J. Mol. Biol. 279, 889-900

77. Bantleon, R., Altenbuchner, J., and van Pée, K.H. (1994) J. Bacteriol. 176, 2339-2347

78. Wiesner, W., van Pée, K.H., and Lingens, F. (1988) J. Biol. Chem. 263, $13725-13732$

79. Cheeseman, J.D., Tocilj, A., Seongsoon, P., Schrag, J.D., and Kazlauskas, R. (2004) Biological Crystallography 60, 1237-1243

80. Schrijver, A.D., Nagy, I., Schoofs, G., Proost, P., Vanderleyden, J., van Pée, K.H., and Mot, R.D. (1997) Appl. Environ. Microbiol. 63, 1911-1916 
81. Burd, W., Yourkevich, O., Voskoboev, A.J., and van Pée, K.H. (1995) FEMS Microbiol. Lett. 129, 255-260

82. Preobrazhenskaya, Y.V., Voskoboev, A.I., and Burd, V.N. (2003) FEBS Lett. 536, 41-44

83. Carboni-Oerlemans, C., Domínguea de María, P., Tuin, B., Bargeman, G., van der Meer, A., and van Gemert, R. (2006) J. Biotechnol. 126, 140-151

84. van Peé, K.H., Dong, C., Flecks, S., Naismith, J., Patallo, E.P., and Wage, T. (2006) Adv. Appl. Microbiol. 59, 127-157

85. Yeh, E., Garneau, S., and Walsh, C.T. (2005) Proc. Natl. Acad. Sci. U.S.A. 102, 3960-3965

86. Neumann, C.S., Walsh, C.T., and Kay, R.R. (2010) Proc. Natl. Acad. Sci. U.S.A. 107, 5798-5803

87. Burd, V.N., and van Pee, K.H. (2003) Biochemistry (Moscow) 68, 11321135

88. Fujimori, D.G., Hrvatin, S., Neumann, C.S., Strieker, M., Marahiel, M.A., and Walsh, C. (2007) Proc. Natl. Acad. Sci. U.S.A. 104, 16498-16503

89. Smith, S. (2002) Chem. Biol. 9, 955-956

90. Saito, T., Kato, A., and Kay, R.R. (2008) Dev. Biol. 317, 444-453

91. Otsuka, M., Ichinose, K., Fujii, I., and Ebizuka, Y. (2004) Antimicrob. Agents Chemother. 48, 3468-3476 


\title{
CHAPTER 2
}

Halogenation Enzymes in Bacteria Associated with the Red-Banded Acorn Worm, Ptychodera jamaicensis

Milena Lilles ${ }^{1}$, Sabine Rech ${ }^{1}$, Joseph B. White ${ }^{1}$, and Roy Okuda ${ }^{2}$

${ }^{1}$ From the Department of Biological Sciences, San Jose State University, San Jose, CA 95192

${ }^{2}$ From the Department of Chemistry, San Jose State University,

San Jose, CA 95192

\author{
Correspondence to: \\ Milena Lilles \\ Department of Biological Sciences \\ One Washington $\mathrm{Sq}$ \\ San Jose, CA 95192 \\ E-mail: mlilles@yahoo.com \\ Date submitted: October 2011
}




\section{Introduction}

Organohalogens have numerous impacts on organisms and the environment. Many organohalogens such as DDT and CFCs are man-made environmental pollutants, but there are more than 3,800 organohalogens produced naturally in the environment (1). These compounds persist in the environment due to the lipid solubility of their halogen subunit, which also decreases their water solubility (2). Organohalogens are relatively stable chemicals. Many organisms bioaccumulate halogenated compounds as defensive chemicals, which also have antibiotic and/or anti-cancer properties. Halogenated compounds are useful as pharmaceuticals because they can penetrate lipid membranes to reach their cellular target. It is important to identify strains of bacteria that have halogenation enzymes to better understand the context in which they are produced and to discover new biopharmaceuticals and enzymatic pathways. Halogenation enzymes can also be used in environmentally sustainable chemical reactions.

The main halogenation enzymes are the haloperoxidases and $\mathrm{FADH}_{2}$-dependent halogenases. These halogenation enzymes are attractive alternatives for use in chemical halogenation processes because haloperoxidases oxidize halogens with hydrogen peroxide and the $\mathrm{FADH}_{2}$-dependent halogenases use oxygen. Water is the side product formed. These enzymes would decrease the need for toxic molecular halogens and petroleum-based chlorinated solvents in the production of halogenated organics (3). The perhydolases or cofactor-free haloperoxidases from bacteria can be enzymatically coupled with enzymes, such as glucose oxidase to enhance the efficiency of bleaching processes in the textile and paper industries. More than $60 \%$ of the world's production of 
hydrogen peroxide is consumed in these processes (3). Glucose oxidase is an enzyme that generates hydrogen peroxide, which is used by perhydrolases to form peracids (4). Modified enzymes can reduce the use of hydrogen peroxide, peracids, and chlorinated waste products in bleaching processes. Biomimetic research focuses on how these enzymes are used naturally to produce organohalogens. This knowledge can be used to develop bioengineered enzymes and products.

One source of these enzymes is marine acorn worms, which produce many organohalogens including bromophenols, bromopyrroles, bromo- and chloroindoles, bromohydroquinones, and bromo-cyclohexanes $(5,6)$. These compounds may act as chemical deterrents to encroaching organisms. Bacteria present on or in these worms may synthesize halogenation enzymes that are involved in the production of these compounds. In Streptomyces, vanadium chloroperoxidases produce the chlorinated antibiotic napyradiomycin. In general, $\mathrm{FADH}_{2}$-dependent halogenases produce most of the halogenated antibiotics in bacteria $(7,8-17)$. This study investigates if bacteria associated with the red-banded acorn worm Ptychodera jamaicensis have halogenation genes and the capacity to synthesize halogenated compounds.

Forty-eight bacterial strains were isolated from the slime associated with the acorn worm and a phylogenetic tree was constructed based on the 16S rDNA gene of each isolate. Genomic DNA was screened for bromoperoxidase and $\mathrm{FADH}_{2}$-dependent halogenase genes to ascertain if the bacteria are capable of synthesizing these enzymes and possibly organohalogens. Bromoperoxidase primers were designed from the bromoperoxidase consensus sequence of five Bacillus strains, and $\mathrm{FADH}_{2}$-dependent 
halogenase primers were ordered based on the work of Hornung et al. (18). To test the isolates for bromoperoxidase activity, the enzymes were partially purified from crude protein extracts with ammonium sulfate precipitation and anion exchange chromatography. Activity was measured with a phenol red and monochlorodimedone assay. 


\section{Experimental Procedures}

$16 S$ rDNA Amplification, Sequencing and Phylogenetic Analysis-The genomic

DNA of 48 bacterial isolates from the slime of the red-banded acorn worm, Ptychodera jamaicensis was extracted using a Midi-Prep Kit for Isolation of Genomic DNA for bacteria (Qiagen, Valencia, CA). The bacterial 16S rDNA gene was amplified using the 16S ribosomal DNA universal bacterial Fd1 and Rd1 primers (19). Primers were synthesized by Operon Biotechnologies, Inc. (Huntsville, AL). A $40 \mu \mathrm{l}$ PCR reaction contained: $8 \mu \mathrm{l}$ 5X PCR Buffer, $4 \mu \mathrm{Fd} 1$ and Rd1 primers $(10 \mu \mathrm{M})$ each, $8 \mu \mathrm{l}$ dNTPs (1mM), $4 \mu \mathrm{MgCl}_{2}(25 \mathrm{mM}), 0.6 \mu \mathrm{l} \mathrm{Taq} \mathrm{Polymerase}(5 \mathrm{u} / \mu \mathrm{l}), 7.4 \mu \mathrm{H}_{2} \mathrm{O}$, and $4 \mu \mathrm{l}$ genomic DNA (.3 ng). The PCR was performed in a MJ Research PTC-100 ${ }^{\circledR}$ Peltier Thermal Cycler (Global Medical Instrumentation, Inc., Ramsey, MN) under the following cycling conditions: 1) denaturation for 2 min at $95^{\circ} \mathrm{C}$, followed by 2) 34 cycles of denaturation for $15 \mathrm{sec}$ at $95^{\circ} \mathrm{C}$, annealing of primers for $30 \mathrm{sec}$ at $55^{\circ} \mathrm{C}$, extension of primers for $2 \mathrm{~min}$ at $72^{\circ} \mathrm{C}$, and 3) a final extension for $6 \mathrm{~min}$ at $72^{\circ} \mathrm{C}$. The presence of the 16S rDNA gene was confirmed with gel electrophoresis using $1.5 \%$ agarose gels. The gels were stained with ethidium bromide and visualized with ultraviolet light in a GelDoc ${ }^{\mathrm{TM}}$ XT 170-8171 (BioRad Laboratories, Hercules, CA).

The isolates that showed a positive result for the 1.5-kilobase 16S rDNA gene were purified using a QIAquick ${ }^{\circledR}$ PCR purification kit (Qiagen, Valencia, CA). After purification, they were sent for sequencing to Sequetech Corporation (Mountain View, CA). The returned sequences were analyzed and edited with 4peaks software (http://www.mekentosj.com/science/4peaks). A basic local alignment search tool 
(BLAST) search was performed using nucleotide blast

(http://blast.ncbi.nlm.nih.gov/Blast.cgi, 20). The closest similarity matches for each 16S rDNA sequence were aligned using ClustalW2-Multiple Sequence Alignment (http://www.ebi.ac.uk/Tools/msa/clustalw2/, 21, 22). The aligned nucleotide sequences were saved in Fasta format and converted to a molecular evolutionary genetics analysis (MEGA) file to build a neighbor-joining phylogenetic tree with MEGA software (23). The out-group was the cyanobacterium Nostoc sp. PCC 7120, and Bacillus cereus and Escherichia coli were included as reference type strains.

The 16S rDNA PCR products that did not yield a sequence were cloned into pGEM $^{\circledR}$-T Easy plasmid vectors (Promega, Madison, WI) according to manufacturer's instructions. The plasmids were used to transform competent E. coli JM109 cells (Promega, Madison, WI) or competent E. coli DH5 $\alpha$ cells prepared with a calcium chloride protocol. The plasmids were purified using a Wizard Plus SV Miniprep Kit (Promega, Madison, WI) and screened by restriction analysis using EcoR1 (12u/ $\mu \mathrm{l})$. The plasmids with the $1.5 \mathrm{~kb} 16 \mathrm{~S}$ rDNA gene were sent to Sequetech Corporation (Mountain View, CA) for unidirectional sequencing of 1,000 nucleotides with the forward primer M13F.

Bromoperoxidase Amplification, Sequencing, and Phylogenetic AnalysisBromoperoxidase primers were designed based on the aligned sequences of five bacterial bromoperoxidases from the genus Bacillus. Bacillus anthracis str. "Ames Ancestor", Bacillus cereus AH820, Bacillus cereus ATCC 10987, Bacillus cereus B4264, and 
Bacillus cereus G9842 were the five species used for selecting the bromoperoxidase consensus sequence. The forward and reverse primer sequences are: Fd-BPO 5'-CCC ATG TGG ACC ACC CTT TAT-3' and Rv-BPO 5'-TAA GTG GTC GAT CTT GGG AAT-3'. These primers were used to screen genomic DNA samples of bacteria associated with the red-banded acorn worm. The PCR reaction and cycling conditions were the same used for the $16 \mathrm{~S}$ rDNA gene amplification, but with the bromoperoxidase primers.

The bromoperoxidase primers amplified a 700-base-pair (bp) fragment that was visualized with gel electrophoresis using $1.5 \%$ agarose gels. Each 700-bp bromoperoxidase gene fragment obtained was purified using the QIAquick ${ }^{\circledR}$ PCR purification kit (Qiagen, Valencia, CA) and sent to Sequetech Corp. (Mountain View, CA) for sequencing. The identity of the sequences was confirmed with a BLAST search (http://blast.ncbi.nlm.nih.gov/Blast.cgi). The genomic DNA from Bacillus cereus was used as the positive control, and a sterile water sample was the negative control. The genomic DNA from the gram-negative bacterium Escherichia coli and the archaeon Methanosarcina mezai were also screened for the bromoperoxidase gene fragment. This was to test if the primers are specific for bromoperoxidases from the Bacillus genus. The primers may have a broad range and amplify bromoperoxidase genes in other bacterial genera.

Bromoperoxidase sequences from the bacteria Bacillus cereus G9842, Nocardiopsis dassonvillei subsp. dassonvillei DSM 43111, and Streptomyces sp. Mg1 were aligned with the bromoperoxidase from isolate I37 using ClustalW2 
(http://www.ebi.ac.uk/Tools/msa/clustalw2/). The Clustal alignment was done to visualize similarity between the bromoperoxidase from isolate I37 with bromoperoxidases from other genera. A neighbor-joining bromoperoxidase phylogenetic tree was constructed using MEGA to compare the relatedness of the bromoperoxidase from isolate $\mathrm{I} 37$ with bromoperoxidases from red algae, brown algae, and other bacteria (23). The aligned bromoperoxidase sequences were from the red algal Corallina officinalis, the brown algal Laminaria digitata, and the bacteria Bacillus cereus G9842, Bacillus anthracis, Nocardiopsis dassonvillei susbp. dassonvillei DSM 43111, Streptomyces sp. Mg1, and Synechococcus sp. CC9311.

Bromoperoxidase Purification: Sonication, Ammonium Sulfate Precipitation, and Anion-Exchange Chromatography-Eight isolates positive for the bromoperoxidase gene fragment were grown to an optical density (OD) between $0.6-0.8$ at $600 \mathrm{~nm}$ in $1.5 \mathrm{~L}$ of nutrient broth ( $7.5 \mathrm{~g}$ tryptone-peptone, $3.75 \mathrm{~g}$ beef extract) supplemented with $0.10 \mathrm{~g} \mathrm{KBr}$ and $9.38 \mathrm{~g} \mathrm{NaCl}$. The cells were collected using a Sorval RC2-B centrifuge at $4^{\circ} \mathrm{C}, 5,000$ rpm for $10 \mathrm{~min}$. They were washed twice with $5 \mathrm{ml}$ phosphate buffered saline $(0.1 \mathrm{M}$ PBS, pH 7) and pelleted at $4^{\circ} \mathrm{C}, 14,000 \mathrm{rpm}$ for $10 \mathrm{~min}$. Each wash included resuspension and pelleting. The cells were resuspended in 5-10 $\mathrm{ml}$ of $50 \mathrm{mM}$ Tris- $\mathrm{HCl}$, pH 7.4, and sonicated with a Branson sonic power Sonifier cell disruptor 350 (Branson Ultrasonics Corp., Danbury, CT). They were sonicated using a microtip for six cycles of $30 \mathrm{sec}$ with a $90 \mathrm{sec}$ cooling period at $160 \mathrm{~W}, 50 \%$ duty cycle. The sonicated cells were 
centrifuged at $4^{\circ} \mathrm{C}, 14,000 \mathrm{rpm}$ for $1 \mathrm{~h}$ and the supernatant kept at $-20^{\circ} \mathrm{C}$ for no more than $48 \mathrm{~h}$.

The crude protein extracts were concentrated using ammonium sulfate precipitation. Ammonium sulfate was added to the crude protein extracts at $60 \%$ saturation and the solutions were stirred in a cold room maintained at $4^{\circ} \mathrm{C}$ or below for 30 min. After this time interval, the protein mixture was centrifuged at $4^{\circ} \mathrm{C}, 15,000 \mathrm{rpm}$ for 10 min. The supernatant from the $60 \%$ ammonium sulfate protein pellet was discarded and the pellet kept at $4^{\circ} \mathrm{C}$ for $48-72 \mathrm{~h}$ before further purification with anion-exchange chromatography.

A $1 \mathrm{ml}$ HiTrap Q XL column was used for anion exchange chromatography (GE Healthcare, Piscataway, NJ). The column was first washed with $5 \mathrm{ml}$ of $20 \mathrm{mM}$ Tris$\mathrm{HCl}, \mathrm{pH} 8$, at a flow rate of $1 \mathrm{ml} / \mathrm{min}$ to remove preservatives. Then $5 \mathrm{ml}$ of $20 \mathrm{mM}$ Tris$\mathrm{HCl}$ containing $1.0 \mathrm{M} \mathrm{NaCl}$ was used to equilibrate the column. Before the protein sample was added, the column was equilibrated again with $5 \mathrm{ml}$ of the start buffer (20 $\mathrm{mM}$ Tris- $\mathrm{HCl}, \mathrm{pH} 8$ ). The $60 \%$ ammonium sulfate protein pellet was resuspended in 5 $\mathrm{ml}$ of $20 \mathrm{mM}$ Tris- $\mathrm{HCl}, \mathrm{pH} 8$, and loaded onto the chromatography column. Proteins were eluted from the column with $5 \mathrm{ml}$ samples of start buffer (20 mM Tris- $\mathrm{HCl}, \mathrm{pH} 8$ ) containing increasing amounts of sodium chloride. The sodium chloride step gradient consisted of $5 \mathrm{ml}$ of $0.15 \mathrm{M} \mathrm{NaCl}, 0.25 \mathrm{M} \mathrm{NaCl}, 0.35 \mathrm{M} \mathrm{NaCl}$, and $0.45 \mathrm{M} \mathrm{NaCl}$ dissolved in the start buffer, $20 \mathrm{mM}$ Tris- $\mathrm{HCl}, \mathrm{pH} 8$. Each step consisted of $5 \mathrm{ml}$, and the collected fractions were $5 \mathrm{ml}$. The $5 \mathrm{ml}$ eluents from the column were concentrated using 10,000 molecular weight Amicon ${ }^{\circledR}$ Centricon ${ }^{\circledR}$ centrifugal filter devices (Billerica, MA) 
according to manufacturer's instruction. The concentrated protein fractions with molecular weights greater than $10 \mathrm{kDa}$ were applied to native polyacrylamide gels for electrophoresis.

PhastSystem ${ }^{T M}$ Separation of Proteins and Coomassie Staining-Proteins were separated with native polyacrylamide gel electrophoresis (PAGE) using the PhastSystem ${ }^{T M}$ (Amersham Biosciences, Piscataway, NJ). Two $\mu$ samples from the concentrated protein samples, the positive and negative controls, and a high-molecular weight (HMW) ladder were loaded onto 8-25\% gradient polyacrylamide gels (Amersham Biosciences, Piscataway, NJ). The positive control for bromoperoxidase activity was the bromoperoxidase from the red alga Corallina officinalis (Sigma Aldrich, St. Louis, MO). The negative control was boiled bovine serum albumin (Promega Corp., Madison, WI). After protein separation and the phenol red gel assay, the gels were transferred to the PhastSystem $^{\mathrm{TM}}$ (Amersham Biosciences Corp., Piscataway, NJ) for Coomassie ${ }^{\mathrm{TM}}$ staining with PhastGel BlueR (Amersham Biosciences Corp., Piscataway, NJ). The HMW protein ladder was used to determine approximate protein weights.

Phenol Red Gel Assay-After protein separation, the gels were placed in $10 \mathrm{ml}$ of a phenol red assay solution and $100 \mu \mathrm{l}$ of $1 \% \mathrm{H}_{2} \mathrm{O}_{2}$ was added to begin the reaction. The phenol red assay solution consisted of: $1 \mathrm{M}$ sodium acetate buffer, $1 \mathrm{M}$ sodium bromide, and $0.002 \%$ phenol red at a $\mathrm{pH}$ of 5.5 . The gels were observed for $30 \mathrm{~min}$ for bromoperoxidase activity. After twenty min, approximately $100 \mu \mathrm{l}$ of $1 \%$ hydrogen 
peroxide was added again to ensure other enzymes did not deplete the hydrogen peroxide. The phenol red substrate undergoes a color change from yellow to blue when phenol red is brominated, as shown in Figure 2. The appearance of blue protein bands in the polyacrylamide gels was the result of the formation of bromophenol blue and indicated a positive protein sample with bromoperoxidase activity.
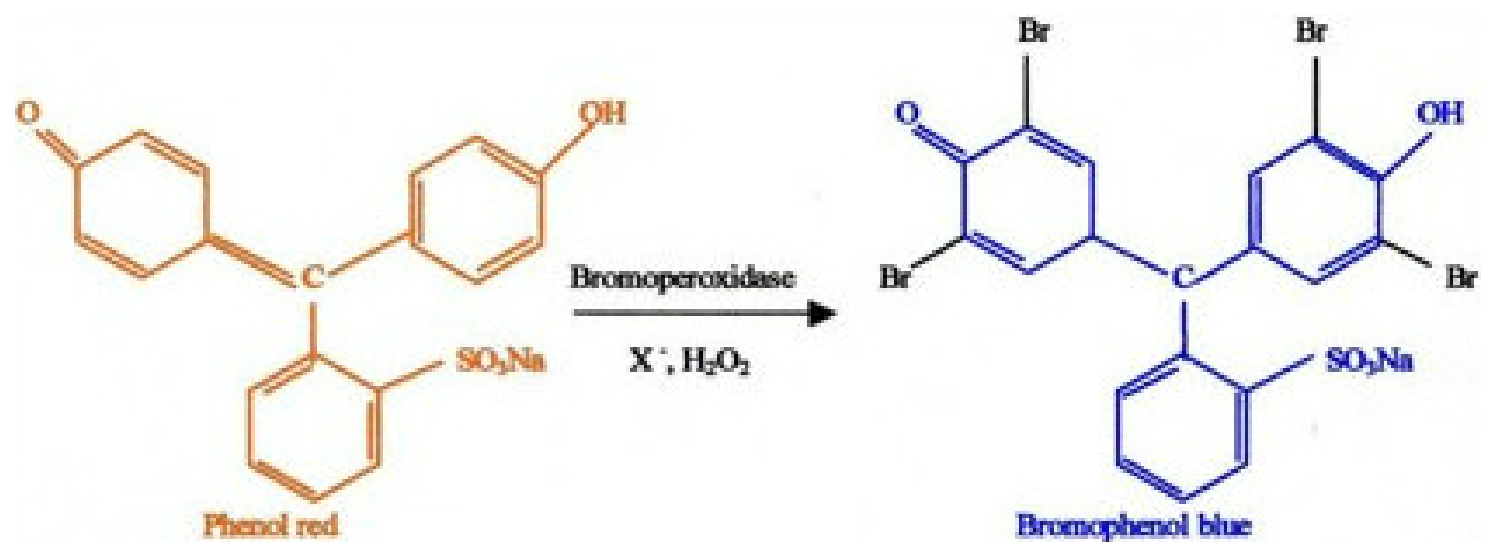

Figure 2. The Phenol Red Assay.

Monochlorodimedone Assay-The protein fractions positive for bromoperoxidase activity in the phenol red gel assay were tested in the monochlorodimedone (MCD) assay. This continuous spectrophotometric assay monitors the decrease in absorbance of $\mathrm{MCD}$ at a wavelength of $290 \mathrm{~nm}$ (Fig. 1). It is carried out at $25^{\circ} \mathrm{C}$ in $0.1 \mathrm{M}$ sodium acetate buffer, $0.1 \mathrm{M}$ potassium bromide, and $50 \mu \mathrm{M} \mathrm{MCD}$ at a $\mathrm{pH}$ of 5.5. This buffer (1 ml) was added to a quartz cuvette along with $20 \mu \mathrm{l}$ of the bromoperoxidase active protein sample. Hydrogen peroxide at a concentration of $8.8 \mathrm{mM}$ was added to begin the 
bromoperoxidase reaction. If bromoperoxidase activity was not detected after $20 \mathrm{~min}$, $100 \mu \mathrm{l}$ of $1 \%$ hydrogen peroxide was added to ensure enough substrate in the reaction.

The conversion of $1 \mu \mathrm{mol}$ of MCD in $1 \mathrm{~min}$ is defined as one unit (U) of enzyme activity (24). The MCD substrate can be chlorinated or brominated depending on the haloperoxidase and halides present. Eventually all the MCD is consumed and the OD reaches zero, indicating reaction termination.

Bacterial Growth Curve of Isolate I37-A 3 L nutrient broth culture of isolate I37 was grown in a $6 \mathrm{~L}$ round bottom flask. The culture was maintained between $23^{\circ} \mathrm{C}$ and $25^{\circ} \mathrm{C}$ with shaking at $150-250 \mathrm{rpm}$ for $48 \mathrm{~h}$. The $\mathrm{OD}$ at $600 \mathrm{~nm}$ was taken every hour to generate a bacterial growth curve.

$\mathrm{FADH}_{2}$-Dependent Halogenase Amplification, Sequencing and Phylogenetic Analysis-The genomic DNA of the isolates was screened with the degenerate $\mathrm{FADH}_{2}$ dependent halogenase primers, Halo-B4-FW 5'-TTC CCS CGS TAC CAS ATC GGS GAG-3' and Halo-B7-RV 5'-GSG GGA TSW MCC AGW ACC ASC C-3' (18). The primers allow for wobble between bases. The base "S" can code for either a cytosine or thymine, a "W" codes for a guanine or cytosine, and an "M" codes for either adenine or cytosine. The $50 \mu \mathrm{l} \mathrm{PCR}$ reaction contained: $10 \mu \mathrm{l}$ XX PCR buffer, $3 \mu$ Halo-B4-FW and Halo-B7-RV primers (10 $\mu \mathrm{M}$ each), $2 \mu \mathrm{dNTPs}(10 \mathrm{mM}), 5 \mu \mathrm{l} \mathrm{MgCl}_{2}(25 \mathrm{mM}), 0.5$ $\mu \mathrm{l}$ Taq Polymerase ( $5 \mathrm{u} / \mu \mathrm{l}), 22.5 \mu \mathrm{l} \mathrm{H}_{2} \mathrm{O}$, and $4 \mu \mathrm{l}$ genomic DNA (0.2 ug). The PCR was performed under the following cycling conditions: 1) denaturation for 3 min at $94^{\circ} \mathrm{C}$, 
followed by 2) 30 cycles of denaturation for $1 \mathrm{~min}$ at $94^{\circ} \mathrm{C}$, annealing of primers for 1.5 min at $58^{\circ} \mathrm{C}$, extension of primers for $1 \mathrm{~min}$ at $72^{\circ} \mathrm{C}$, and 3) a final extension for $5 \mathrm{~min}$ at $72^{\circ} \mathrm{C}$.

Isolates that had a 1,000-bp gene fragment in the $1.5 \%$ agarose gel were purified with the QIAquick ${ }^{\circledR}$ PCR purification kit (Qiagen, Valencia, CA) and sent for sequencing to Sequetech Corp. (Mountain View, CA). The returned 1,000-bp halogenase sequence from isolate X36 was analyzed with a BLAST search (http://blast.ncbi.nlm.nih.gov/Blast.cgi) and aligned with tryptophan halogenases from Paenibacillus sp. JDR-2 and Bacillus cereus subsp. cytotoxis NVH 391-98 using ClustalW2 (http://www.ebi.ac.uk/Tools/msa/clustalw2/). A neighbor-joining phylogenetic tree was constructed using MEGA software to compare various halogenases from different genera of bacteria (23). The phylogenetic tree consisted of the halogenase from isolate X36 and halogenases from Micromonospora sp., Salinospora arenicola, Paenibacillus sp. JDR-2, Streptosporangium nondiastaticum, Pseudomonas fluorescens Pf-5, Catenulispora acidiphila, Streptomyces griseoflavus, Streptomyces albogriseolus, Nocardia beijingensis, and Bacillus cereus subsp. cytotoxis. 


\section{Results}

$16 S$ rDNA Phylogenetic Tree-The 48 bacterial isolates obtained from the acorn worm are represented in the phylogenetic tree in Figure 3. Each isolate is designated alphanumerically and with a species name. The species name represents the closest BLAST similarity match for each $16 \mathrm{~S}$ rDNA gene. The $16 \mathrm{~S}$ rDNA gene for all of the isolates had a $97 \%$ or greater similarity to the species shown in Figure 3, except for isolates M16 and LL16. These isolates have similarities of 96\% and 93\%, respectively.

Phylogenetic analyses reveal that the bacteria isolated from the red-banded acorn worm Ptychodera jamaicensis belong to the Firmicutes and Actinobacteria phyla (Fig. 3). Thirty-six of the 48 bacterial isolates belong to Firmicutes. They are designated with a pink ellipsis (Fig. 3). Thirty-five of these bacteria are in the family Bacillaceae and one in the Paenibacillaceae. The 36 Firmicutes belong to the genera Bacillus, Halobacillus, Paenibacillus, and Paucisalibacillus. The remaining 12 bacterial isolates are Actinobacteria. Four of these Actinobacteria are in the Micrococcaceae, two from the Microbacteriaceae and Nocardiaceae, and one from the Nocardiopsaceae. The genera of these Actinobacteria include Rhodococcus, Kocuria, Arthrobacter, Streptomyces, Micrococcus, Curtobacterium, Microbacterium, and Janibacter.

The 16S rDNA phylogenetic tree was constructed using the neighbor-joining method, and bootstrap values are shown at the tree nodes. The bootstrap values are percentages in which the taxa associated cluster together out of 500 replicate trees (25). The bootstrap values are lowest between isolates in the Firmicutes I and Firmicutes II but higher between the Actinobacteria I and II. The highest bootstrap value of 100 occurs 
where the Firmicutes I and Actinobacteria I branch from the Firmicutes II and Actinobacteria II. The Firmicutes I and Actinobacteria I are separated from the Firmicutes II and Actinobacteria II by isolate LL16 (Fig. 3). LL16 is 93\% similar to a Bacillus sp., but is not clustered with either the Firmicutes I or Firmicutes II. Instead, isolate LL16 divides the Actinobacteria I and Actinobacteria II. The bacterial isolates that are positive for the bromoperoxidase gene fragment are highlighted in yellow and found within all Firmicutes and Actinobacteria groups (Fig. 3). The cyanobacterium Nostoc sp. is the out-group, and E. coli and B. cereus were included as reference type strains. 


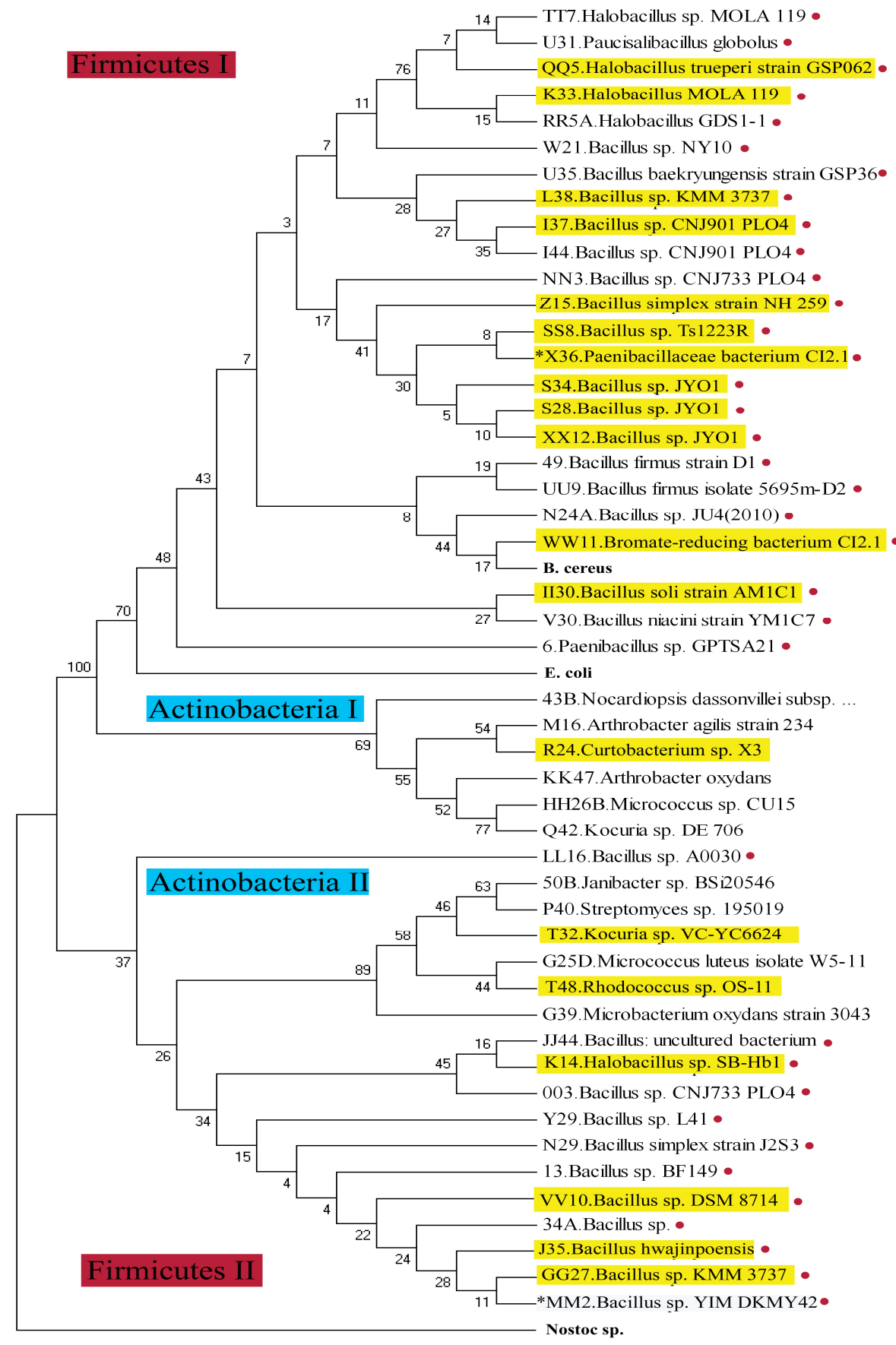

Figure 3. $16 \mathrm{~S}$ rDNA Neighbor-Joining Phylogenetic Tree of Bacterial Isolates. Positive bromoperoxidase isolates are highlighted in yellow and $\mathrm{FADH}_{2}$-dependent halogenase isolates have an asterisk *. 
Bromoperoxidase Genetic Analysis-The genomic DNA from each bacterial isolate was screened for a 700-bp bromoperoxidase gene fragment. Positive bromoperoxidase fragments from bacterial isolates 8, 15, R24, and B. cereus are shown in Figure 4. Nineteen of the 48 bacterial isolates had the 700-bp bromoperoxidase gene. Out of these 19 isolates, 16 are bacteria within the Bacillaceae family (Fig. 3). These Bacillaceae isolates are spread between three genera. Twelve isolates are Bacillus, three are Halobacillus, and one was identified as Paenibacillus. The remaining three isolates with bromoperoxidase genes are Actinobacteria. They are from the genera Curtobacterium, Rhodococcus, and Kocuria.

BLAST analyses of 19 bromoperoxidase gene fragments revealed that ten are 98\% similar to a bromoperoxidase from B. cereus $\mathrm{B} 4264$. The ten bacterial isolates positive for this bromoperoxidase gene are dispersed throughout the Firmicutes and Actinobacteria groups in the phylogenetic tree (Fig. 3). Isolate WW11 is a bromatereducing bacterium with a bromoperoxidase gene fragment $96 \%$ similar to the bromoperoxidase in B. cereus $\mathrm{G} 9842$. The remaining seven isolates have bromoperoxidase gene sequences with at least $89 \%$ similarity to an arylesterase from Bacillus thuringiensis serovar chinensis CT-43. The bromoperoxidase from isolate I37 was one of these seven isolates with $90 \%$ similarity to the arylesterase from $B$. thuringiensis.

The arylesterase from isolate I37 was aligned with bromoperoxidase sequences from Bacillus cereus G9842, Nocardiopsis dassonvillei subsp. dassonvillei DSM 43111, and Streptomyces sp. $\mathrm{Mg} 1$ to compare similarity (Fig. 5). The asterisks in Figure 5 show 
the nucleotide base consensus between the four sequences. The arylesterase sequence from isolate I37 had a 27\% similarity to the bromoperoxidase from B. cereus G9842. This was slightly higher than the $25 \%$ similarity to the bromoperoxidase from Nocardiopsis dassonvillei subsp. dassovillei DSM 43111, and the 23\% similarity to the bromoperoxidase from Streptomyces sp. Mg1. The neighbor-joining phylogenetic tree in Figure 6 shows that the arylesterase from isolate I37 clusters with bromoperoxidases from the Bacillus genus in $99 \%$ of 500 replicate trees. The Bacillus bromoperoxidases are associated with the bromoperoxidase from the brown alga, $L$. digitata. The bacterial bromoperoxidases from the Streptomyces sp. and the cyanobacterium Synechococcus $s p$. are related with a high bootstrap value of 100. The bacterial bromoperoxidase from $N$. dassonvillei and the red algal bromoperoxidase from $C$. officinalis cluster together with a bootstrap of 94 . 


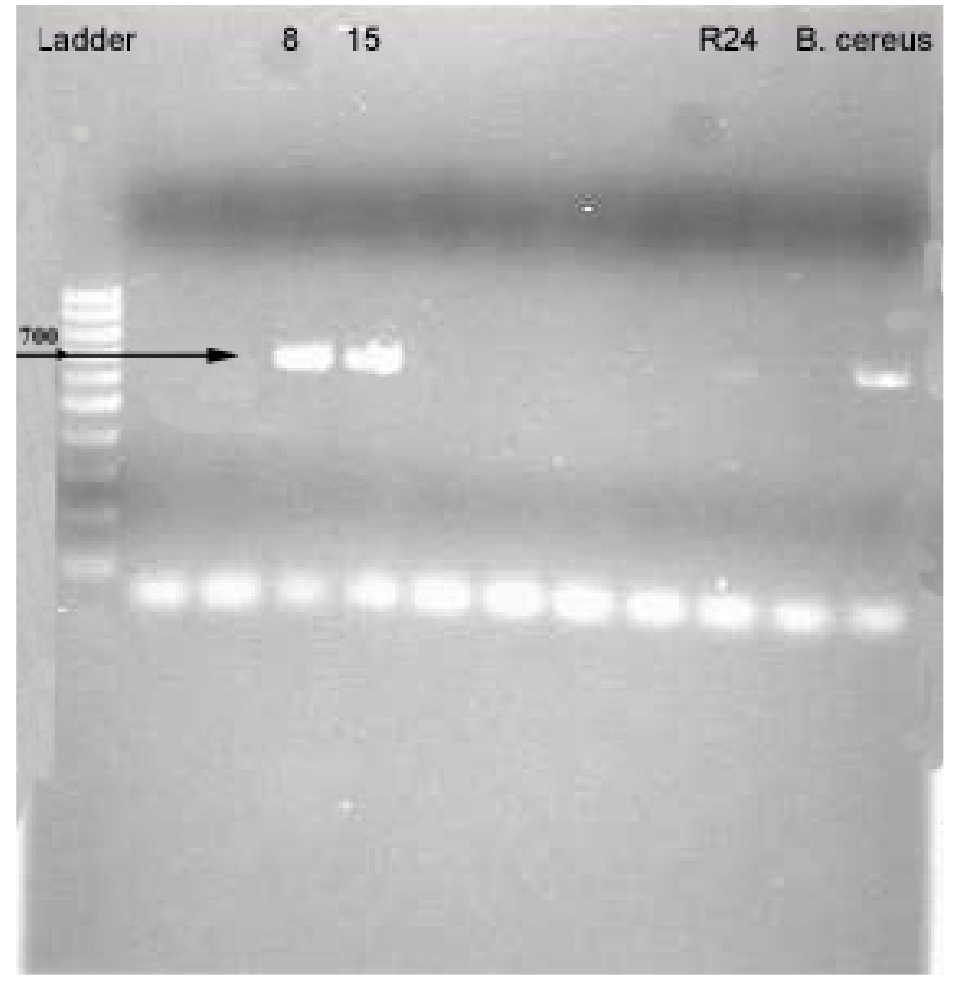

Figure 4. Representative Positive Bromoperoxidase Gel Isolates.

Isolates 8, 15 and R24 have a 700-bp bromoperoxidase gene fragment.

B. cereus is the positive control. 


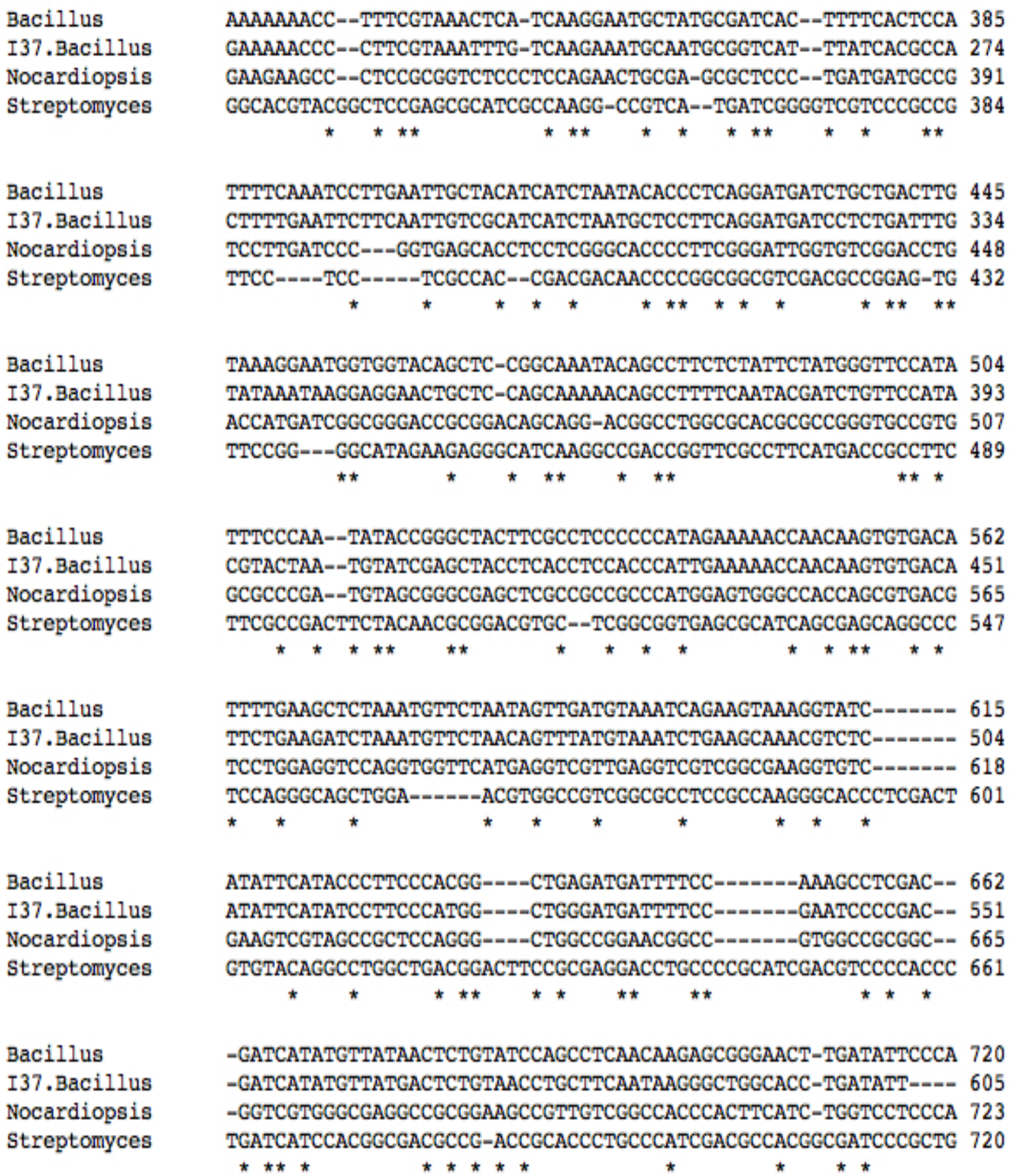

Figure 5. Bromoperoxidase Gene Sequence Alignment Using ClustalW2.

The four aligned bromoperoxidase sequences are from Bacillus cereus G9842, Isolate I37 gene fragment, Nocardiopsis dassonvillei subsp. dassonvillei DSM 43111, and Streptomyces sp. Mg1. 


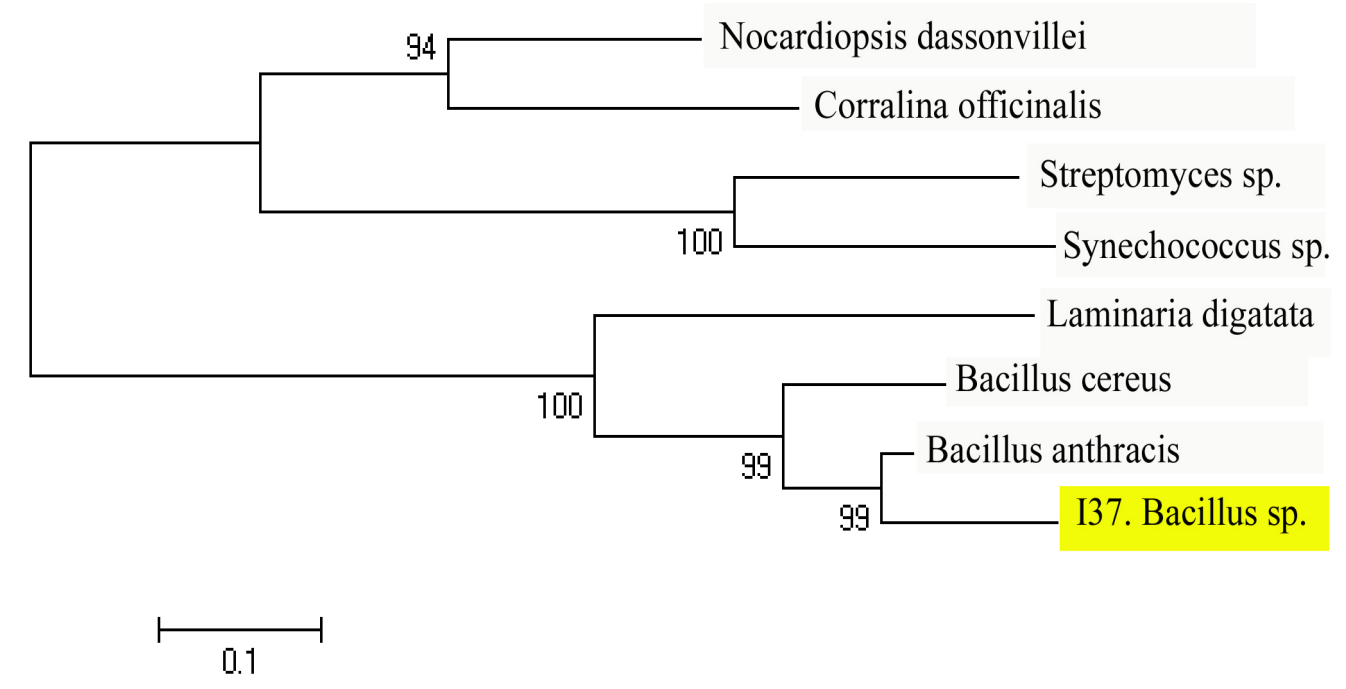

Figure 6. Bromoperoxidase Neighbor-Joining Phylogenetic Tree.

Bromoperoxidase Activity-Eight bacterial isolates with the bromoperoxidase gene fragment were cultured for bromoperoxidase purification. The bacterial cells were collected and sonicated at an OD between $0.6-0.8$ at $600 \mathrm{~nm}$. The proteins from the bacterial isolates were partially purified with ammonium sulfate precipitation and anionexchange chromatography. Bromoperoxidase activity was checked with a phenol red gel assay. Protein fractions with bromoperoxidase activity in the phenol red gel assay were tested in the MCD assay. Two bacterial isolates with bromoperoxidase activity in the phenol red gel assay are shown in Figures 7 and 8.

The bromoperoxidase active proteins from the two isolates have different molecular weights. The bromoperoxidase from isolate I37 has a molecular weight of approximately $67 \mathrm{kDa}$ (Fig. 7), while the bromoperoxidase from isolate $\mathrm{HH} 26$ has a molecular weight of about $232 \mathrm{kDa}$ (Fig. 8). The catalase in the protein ladder of Figure 
8 also shows bromoperoxidase activity and has a molecular weight of $232 \mathrm{kDa}$. The isolates $\mathrm{HH} 26, \mathrm{~S} 34, \mathrm{~T} 48, \mathrm{X} 36$, and $\mathrm{H} 46$ had bromoperoxidase activity in the phenol red gel assay, but not the MCD assay. The bromoperoxidase active proteins from these isolates have varying molecular weights as listed in Table 5. The only isolate with bromoperoxidase activity in both the phenol red and MCD assay was isolate I37, with a molecular weight of $67 \mathrm{kDa}$.

Bromoperoxidase activity was found in the $0.35 \mathrm{M}$ and $0.45 \mathrm{M} \mathrm{NaCl}$ fraction of isolate $\mathrm{I} 37$ (Fig. 7). The $0.35 \mathrm{M} \mathrm{NaCl}$ fraction of isolate $\mathrm{I} 37$ had a protein concentration of $9 \mathrm{mg} / \mathrm{ml}$ based on the Bradford protein assay. The $0.35 \mathrm{M}$ and $0.45 \mathrm{M} \mathrm{NaCl}$ fractions of isolate $\mathrm{I} 37$ were not pure, as seen from the many different proteins depicted in the Coomassie Blue stained gel (Fig. 7). The specific bromoperoxidase activity in the MCD assay of the $0.35 \mathrm{M} \mathrm{NaCl}$ fraction from isolate $\mathrm{I} 37$ was 0.417 units. The conversion of 1 $\mu \mathrm{mol}$ of MCD in $1 \mathrm{~min}$ is defined as one unit (U) of enzyme activity (24). The positive control for the MCD assay was the bromoperoxidase from the red algae Corallina officinalis. The C. officinalis bromoperoxidase had an activity of 5 units in the MCD assay and a molecular weight of approximately $669 \mathrm{kDa}$. The boiled bovine serum albumin negative control did not have bromoperoxidase activity. 


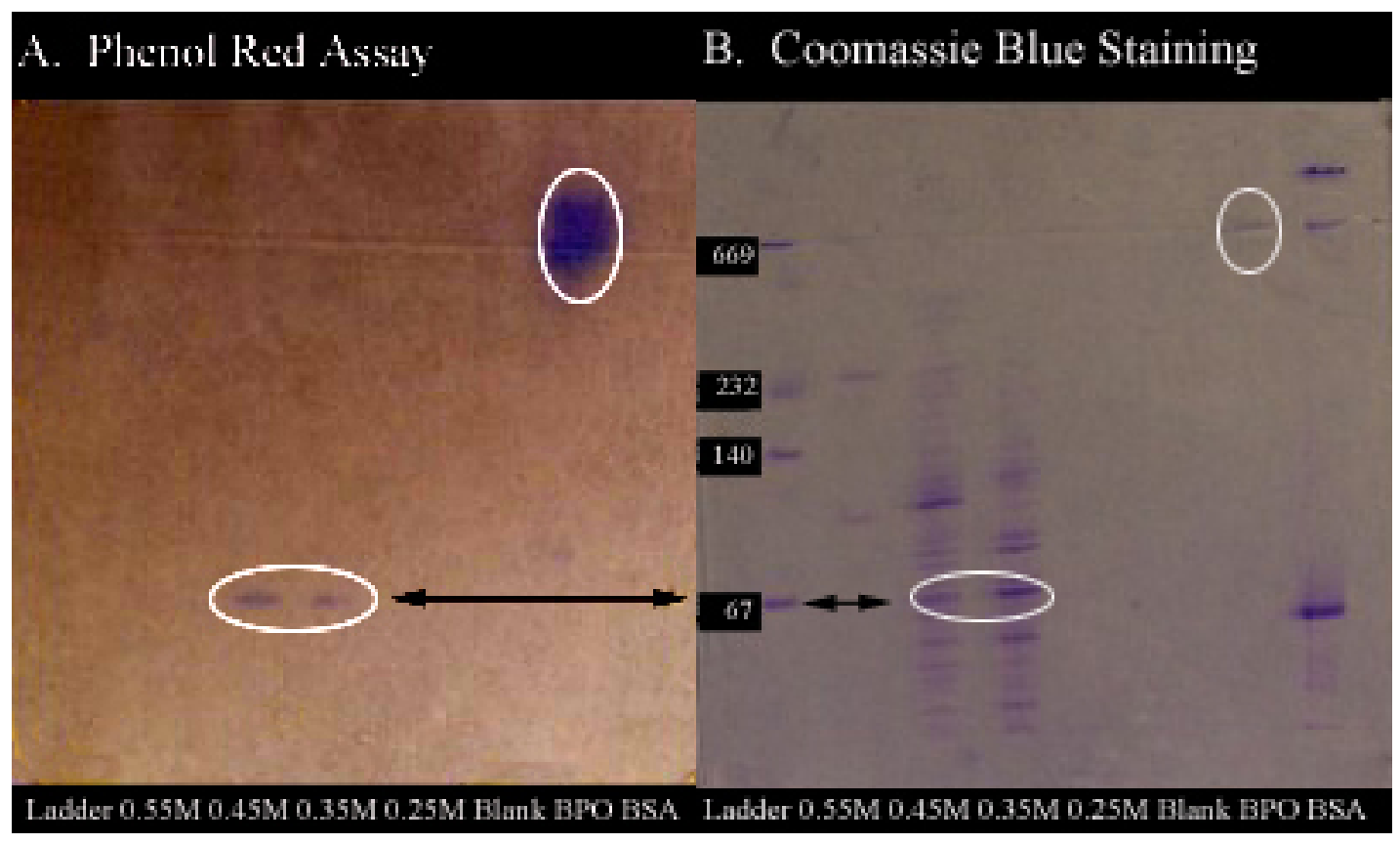

Figure 7. Phenol Red Activity Gel (A) and Coomassie Blue Gel (B) of Isolate I37. A. The bromophenol blue protein bands from the $0.35 \mathrm{M}$ and $0.45 \mathrm{M} \mathrm{NaCl}$ fractions of isolate I37 are circled along with the dark bromophenol blue band from the bromoperoxidase of Corallina officinalis.

B. Both bromoperoxidase active enzymes from isolate I37 show an approximate molecular weight of $67 \mathrm{kDa}$. The bromoperoxidase from Corallina officinalis has a faint band circled around $669 \mathrm{kDa}$. 


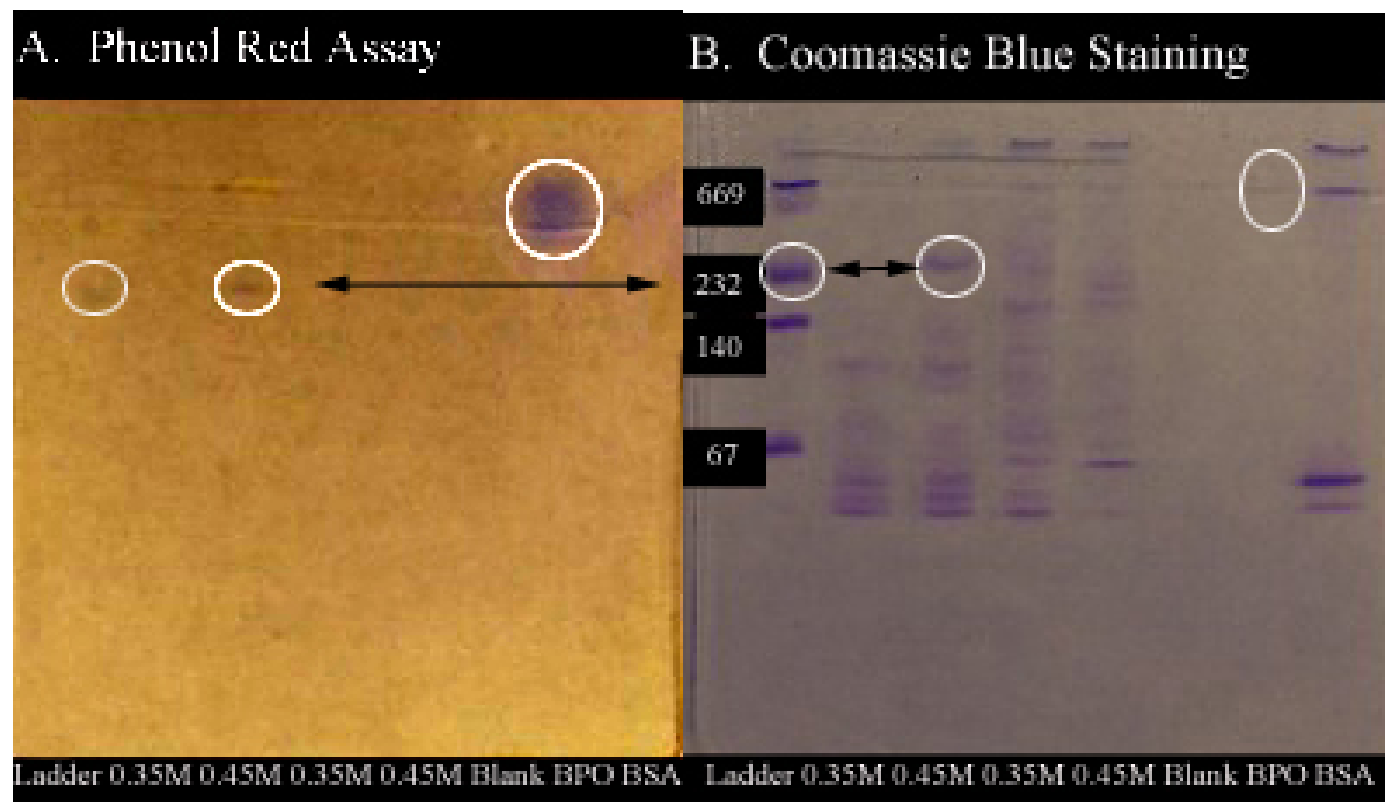

Figure 8. Phenol Red Activity Gel (A) and Coomassie Blue Gel (B) of Isolate HH26. A. The bromophenol blue protein bands from the catalase in the high molecular weight ladder, the $0.45 \mathrm{M} \mathrm{NaCl}$ fraction of isolate $\mathrm{HH} 26$, and the bromoperoxidase of Corallina officinalis are circled.

B. The catalases in the high molecular weight ladder and the bromoperoxidase active enzyme from isolate $\mathrm{HH} 26$ have molecular weights of $232 \mathrm{kDa}$. The bromoperoxidase from Corallina officinalis has a molecular weight around $669 \mathrm{kDa}$.

Table 5. Molecular Weights of Bromoperoxidases from Bacterial Isolates.

\begin{tabular}{|c|c|}
\hline Isolate & $\begin{array}{r}\text { Approximate weight of bromoperoxidase active } \\
\text { enzyme in kilo Daltons (kDa) }\end{array}$ \\
\hline I37 & 67 \\
\hline HH26 & 232 \\
\hline S34 & 232 \\
\hline T48 & 67 \\
\hline X36 & 140 \\
\hline H46 & 232 \\
\hline
\end{tabular}


Bacterial Growth Curve of Isolate I37-Isolate I37 was the only isolate with bromoperoxidase activity in both the phenol red and MCD assays. The bacterial growth curve of isolate I37 is displayed in Figure 9. There was no lag phase in the growth of isolate I37. The doubling time was 17.55 hours at a temperature of $25^{\circ} \mathrm{C}$. The equation $\ln (2) / 0.0395$ was used to calculate the doubling time with a growth rate $=0.0395$. The growth rate is the number of doublings that occur per unit of time (26).

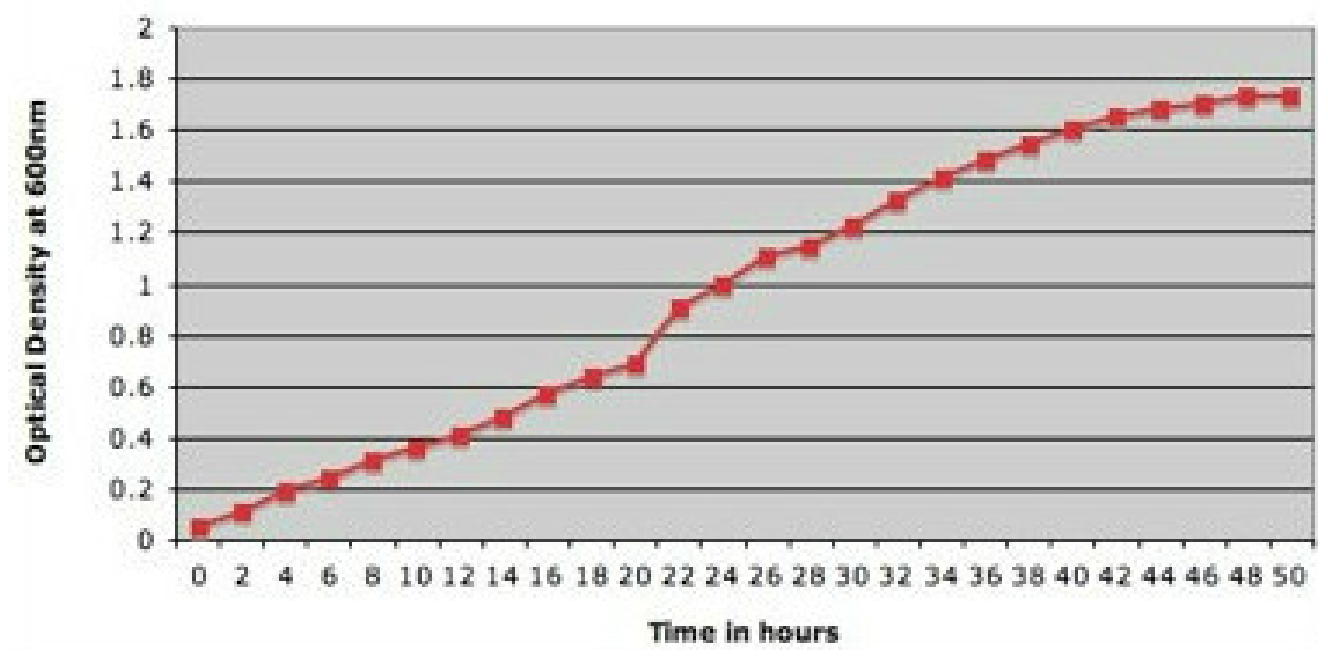

Figure 9. Bacterial Growth Curve of Isolate I37.

$\mathrm{FADH}_{2}$-Dependent Halogenase Genetic Analysis-The $\mathrm{FADH}_{2}$-dependent halogenase primers from Hornung et al. amplified a 1,000-bp halogenase fragment from isolate MM2 and X36 (18). These two isolates are indicated in Figure 3 with an asterisk. Isolate X36 also carries the bromoperoxidase gene on its chromosomal DNA (Fig. 3). Isolate MM2 shows similarity to a Bacillus bacterium from the Firmicutes II group, while isolate X36 is similar to a Paenibacillaceae bacterium from the Firmicutes I group. The 
Firmicutes I group is more similar to the B. cereus group of bacteria than to the Firmicutes II. The amplified 1,000-bp halogenase gene fragment from isolate X36 is displayed in the electrophoresis gel in Figure 10. From a BLAST analysis, the genetic sequence of the halogenase is $71 \%$ similar to a branched chain amino acid transport system II carrier protein from Bacillus cereus B4264. The halogenase gene fragment from isolate MM2 has not been sequenced yet.

For comparison purposes, the halogenases from isolate X36, Paenibacillus $s p$. JDR-2, and Bacillus cereus subsp. cytotoxis NVH 391-98 were aligned using ClustalW2 (Fig. 11). Asterisks indicate nucleotide base consensus between the three aligned halogenases (Fig. 11). The halogenases of isolate X36 and Bacillus cereus subsp. cytotoxis $\mathrm{NVH} 391-98$ have $67 \%$ similarity. The halogenase from isolate $\mathrm{X} 36$ is $66 \%$ similar to the halogenase from the Paenibacillus bacterium. Both halogenases from the Paenibacillus and Bacillus bacteria are tryptophan halogenases. A neighbor-joining phylogenetic tree comparing halogenases from different genera and isolate X36 was constructed with MEGA (Fig. 12). The halogenase from isolate X36 is similar to the halogenase from Bacillus cereus subsp. cytotoxis NVH 391-98 (Fig. 12). The bootstrap value at the node of isolates X36 and Bacillus cereus sp. is 100, which signifies that these halogenases cluster together every time out of 500 replicate trees. 


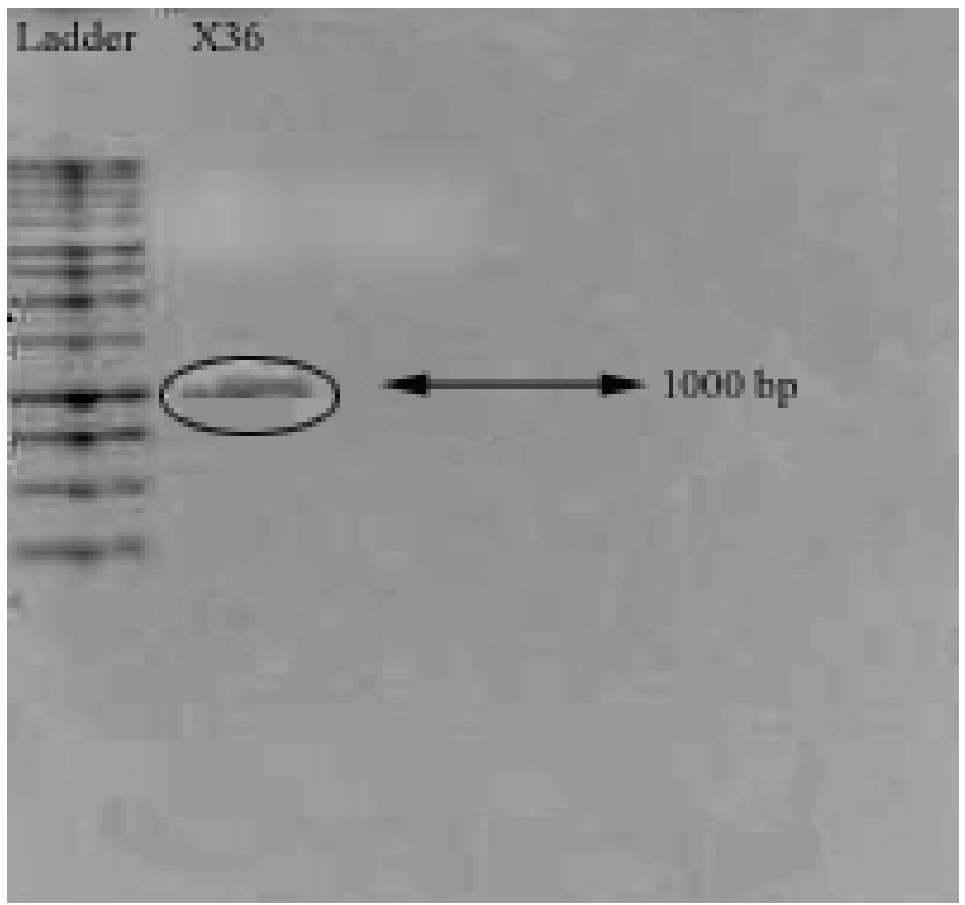

Figure 10. $\mathrm{FADH}_{2}$-Dependent Halogenase from Isolate $\mathrm{X} 36$. Isolate X36 has a 1,000-bp halogenase. 


\author{
X36.Paenibacillaceae \\ Bacillus \\ Paenibacillus
}

X36.Paenibacillaceae Bacillus

Paenibacillus

X36.Paenibacillaceae Bacillus

Paenibacillus

X36.Paenibacillaceae Bacillus

Paenibacillus

X36.Paenibacillaceae Bacillus

Paenibacillus

X36.Paenibacillaceae Bacillus

Paenibacillus

X36.Paenibacillaceae Bacillus

Paenibacillus

X36.Paenibacillaceae Bacillus Paenibacillus

CAAGAAAAGAAGTGTGAGCTACTGTC--TG---AAAGCCCCCCT----AATAGCTGCCA 312 TAAAAAGAGACTACAGGATTATGATC--TTGCCACAGTAAACAT----ATTACCAGATG 688 TGTCATTGGAAGTGACGCCCTGCGCTCGGTTGTGGCGAGAAACCCCAAGGTGAACCGGTA 524

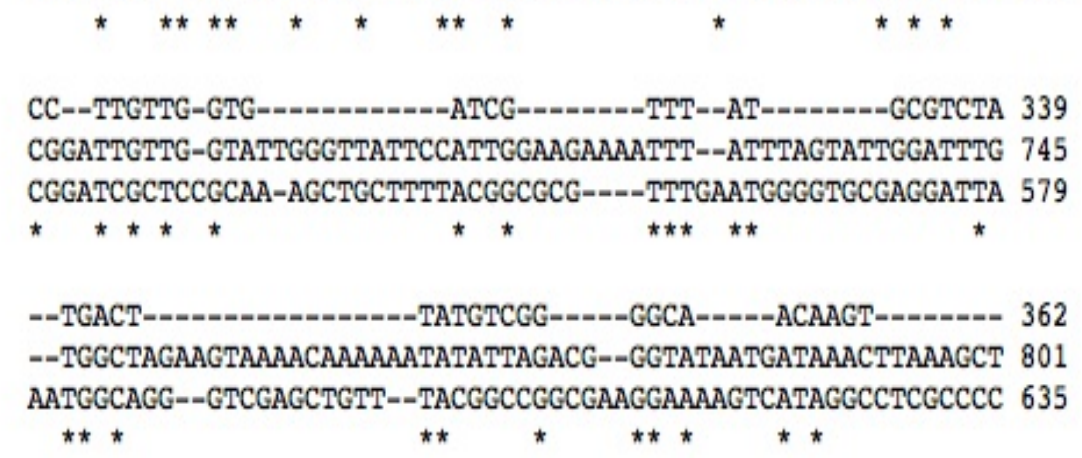

Figure 11. $\mathrm{FADH}_{2}$-Dependent Halogenase Alignment Using ClustalW2.

$\mathrm{FADH}_{2}$-dependent halogenases from Paenibacillus $s p$. JDR-2, Bacillus cereus subsp. cytotoxis NVH 391-98, and Isolate X36 were aligned with ClustalW2. 


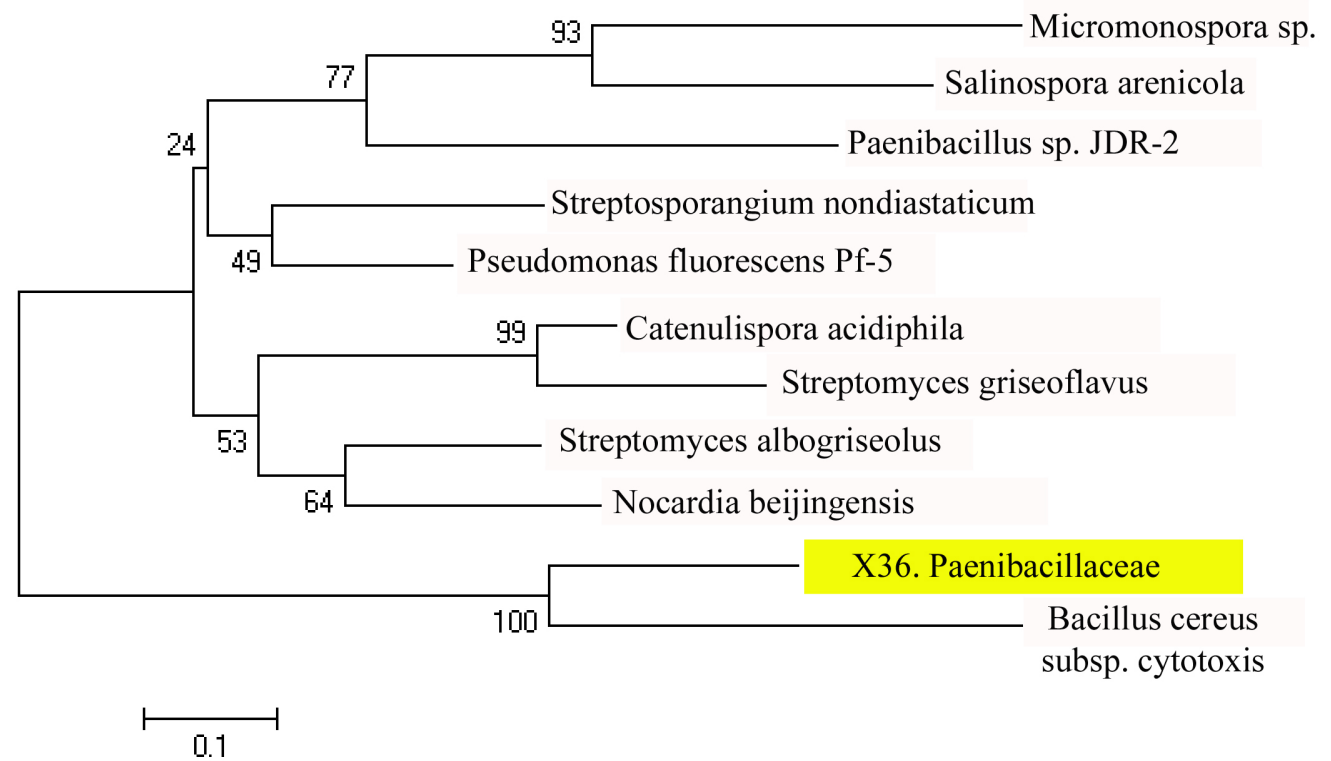

Figure 12. $\mathrm{FADH}_{2}$-Dependent Halogenase Neighbor-Joining Phylogenetic Tree. 


\section{Discussion}

$16 S$ rDNA Phylogenetic Tree-The gram-positive bacteria from the surface of the red-banded acorn worm Ptychodera jamaicensis belong to the Firmicutes and Actinobacteria phyla. There were 36 Firmicutes and 12 Actinobacteria isolated from the acorn worm examined in this study. These isolates appear to be a promising source of natural products found in the marine environment. Bacteria from the Firmicutes and Actinobacteria phyla are the leading producers of antibiotics. The Streptomyces synthesize $34 \%$ of known bioactive microbial metabolites, and Bacillus species produce around 800 antimicrobials (27). The Bacillus genus was the most prominent genus of bacteria present on the acorn worm. Bacteria produce antimicrobials to compete with other microorganisms in the environment. Larger organisms often form symbiotic relationships with bacteria and accumulate these metabolites. The antibiotics produced by epiphytic Bacillus bacteria on the sponge Ircinia fusca prevent other bacteria from colonizing the sponge (28).

The isolates from the acorn worm are members of two distinct subgroups of the Firmicutes and Actinobacteria phyla. The Firmicutes I and Actinobacteria I are related to Bacillus cereus, and the Firmicutes II and Actinobacteria II are related to the Streptomyces sp. (Fig. 3). Some of these isolates belong to novel groups. The isolate 43B is $99 \%$ similar to Nocardiopsis dassonvillei subsp. dassonvillei DSM 43111 and is the starting node of the Actinobacteria I group. The genus Nocardiopsis represents a new actinomycete lineage related to the Actinomadura-ThermomonosporaStreptosporangium-Microtetraspora (ATSM) group of bacteria (29). This genus belongs 
to a new family of bacteria under the name Nocardiopsaceae fam. nov. (29). These bacteria are more similar to the B. cereus group of bacteria than to other Actinobacteria. Bromoperoxidase Genetic Analysis-The bacteria related to the B. cereus group (Firmicutes I and Actinobacteria I) were more likely to have the bromoperoxidase gene fragment than those that were not related to B. cereus. Thirteen bacteria from the Firmicutes I and Actinobacteria I groups, and six bacteria from the Firmicutes II and Actinobacteria II groups have the bromoperoxidase gene. In total, the primers amplified bromoperoxidase genes from 16 Firmicutes and three Actinobacteria. The bromoperoxidase primers do not appear to be specific for Bacillus bacteria, because three Actinobacteria were positive for the bromoperoxidase fragment. More Firmicutes were expected to have the bromoperoxidase gene as there were 27 Bacillus isolates on the worm.

The bromoperoxidase primers were designed from a consensus region of five bromoperoxidases from the B. cereus group of bacteria. The Bacillus strains were Bacillus anthracis str. "Ames Ancestor", Bacillus cereus AH820, Bacillus cereus ATCC 10987, Bacillus cereus B4264, and Bacillus cereus G9842. The B. cereus group includes Bacillus cereus, Bacillus anthracis, and Bacillus thuringiensis. These bacteria have high economic, medical, and biodefense importance (30). Some argue that B. cereus, $B$. thuringiensis, and B. anthracis are essentially the same, except B. cereus does not have the plasmid producing toxins found in B. anthracis or B. thuringiensis. The Bacillus anthracis terrorist attacks in 2001 led to the genome sequencing of these three bacteria in 
the B. cereus group. Both B. cereus and B. anthracis have bromoperoxidase genes. B. thuringiensis has a chloroperoxidase gene.

The bromoperoxidase primers amplified 19 bromoperoxidase genes that were closest in similarity to the B. cereus group of bromoperoxidases. Twelve of the bromoperoxidase fragments were similar to bromoperoxidases in Bacillus cereus strains and seven had $89 \%$ or higher similarity to arylesterases in Bacillus thuringiensis. Arylesterases are hydrolases that act on carboxylic ester bonds. The enzymes hydrolyze the substrate phenyl acetate to form phenol and acetate. Arylesterases share the same catalytic triad (Ser-His-Asp) as the cofactor-free haloperoxidases in bacteria. This catalytic triad is found in lipases, esterases, and serine proteases (31). The bromoperoxidases from the B. cereus group of bacteria are cofactor-free haloperoxidases or perhydrolases that belong to the diverse class of alpha/beta $(\alpha / \beta)$ hydrolase fold enzymes. The primers did not amplify bromoperoxidases in the gram-negative $E$. coli or the archaeon, M. mazei. There is no literature on bromoperoxidases isolated from either E. coli or M. mazei, and these samples served as negative controls.

Bromoperoxidase Activity and Bacterial Growth Curve of Isolate I37-Of the eight isolates that had the bromoperoxidase gene and were assayed for bromoperoxidase activity, only isolate $\mathrm{I} 37$ had bromoperoxidase activity in the phenol red gel and MCD assays. One reason for this observation could be that bromoperoxidase expression may only occur at optical densities (ODs) greater than 0.6 at $600 \mathrm{~nm}$. The bacterial cells from isolate $\mathrm{I} 37$ were collected at an OD of 0.8 , while the other isolates were grown to an OD of 0.6. Bacterial bromoperoxidases seem to be expressed in late exponential phase, as in 
the case of the bromoperoxidase isolated and purified from the bacterium Pseudomonas aureofaciens (32). Bacteria may need to grow to higher cell densities to reach the late exponential phase and express the bromoperoxidase. From the growth curve of isolate I37, it is clear that the bacteria were still in the exponential phase of the growth cycle at an OD of 0.8. The stationary phase did not occur until an OD of 1.7 (Fig. 9). The late exponential phase of isolate I37 may be at an OD of 1.0 and higher.

The primary role of cofactor-free bromoperoxidases in bacteria may be to breakdown hydrogen peroxide. The bromoperoxidases may require a hydrogen peroxide rich environment for expression (32-34). This is consistent with the observation that there is a higher accumulation of toxic waste products, including hydrogen peroxide in the late exponential growth phase, which may stimulate the expression of bromoperoxidase genes. In the oceanic sediment, hydrogen peroxide in the seawater is produced from the photochemical reduction of oxygen with dissolved organic matter and ultraviolet light (35). The bacteria may reduce hydrogen peroxide from seawater and produce brominated products. In the laboratory, these enzymes may not be expressed until there is an accumulation of hydrogen peroxide.

The partially purified proteins from eight bacterial isolates positive for the bromoperoxidase gene were tested with the phenol red gel and the monochlorodimedone assay for bromoperoxidase activity. The phenol red gel assay is a quick and easy assay for visualization of enzyme activity, but is not specific for bromoperoxidase activity. Any enzyme that acts as a peroxidase or catalase can give a false positive by degrading hydrogen peroxide, oxidizing bromide and brominating phenol red. Catalases present in 
the protein ladder can brominate phenol red and display the typical bromophenol blue protein bands (Fig. 8). Protein fractions that showed oxygen gas formation after the addition of hydrogen peroxide and had molecular weights close to $232 \mathrm{kDa}$ were considered catalases. The catalases in the high molecular weight protein ladder had a molecular weight of $232 \mathrm{kDa}$. Isolates $\mathrm{HH} 26, \mathrm{~S} 34$, and $\mathrm{H} 46$ had catalase active proteins with similar molecular weights (Table 5).

There are several bacterial bromoperoxidases with catalase, and peroxidase activity. Some of these are bromoperoxidase-catalases. Additional hydrogen peroxide was added to the bromoperoxidase assays to ensure that catalase and peroxidase enzymes were not depleting the hydrogen peroxide needed for halogenation reactions. The bromoperoxidase-catalase from a Streptomyces bacterium has a molecular weight between $127-136 \mathrm{kDa}(33)$. This is unusual in that the molecular weight of most cofactor-free bromoperoxidases is between $30-90 \mathrm{kDa}$. If the bromoperoxidase consists of a single subunit, it usually has a molecular weight of $30 \mathrm{kDa}$. X-Ray diffraction studies show that the bromoperoxidase from Bacillus anthracis str. "Ames Ancestor" has three bromoperoxidase subunits, each approximately $30 \mathrm{kDa}(36)$. The exception to this is a bromoperoxidase from a Pseudomonas sp. with a molecular weight of $154 \mathrm{kDa}(34)$. Therefore, the molecular weight range targeted for these bromoperoxidases was $154 \mathrm{kDa}$ and lower. Isolates I37, T48, and X36 were within this range, but only isolate I37 showed activity in the MCD assay.

Any protein fraction that showed bromoperoxidase activity in the phenol red gel assay was tested for confirmation with the MCD assay. Unfortunately, the MCD assay 
can also yield false positive results. The assay focuses on the decline of MCD and not on the formation of the bromochloroindole product or any other dihalogenated dimedones. In fact, a cytochrome c(6) protein from cyanobacteria and green algae shows haloperoxidase activity in the MCD assay (37). Although isolate I37 has a bromoperoxidase activity of 0.417 units in the MCD assay, it could be a cytochrome enzyme and not a bromoperoxidase. Cytochrome $\mathrm{c}$ assay kits are available to test isolate I37 for activity and rule out this possibility. Sequencing of the protein would also confirm this. The low bromoperoxidase activity of isolate $\mathrm{I} 37$ in the MCD assay could be due to the partial purity of the sample. A number of different proteins were present in both the $0.35 \mathrm{M}$ and $0.45 \mathrm{M} \mathrm{NaCl}$ eluents of isolate $\mathrm{I} 37$ (Fig. 7).

\section{$\mathrm{FADH}_{2}$-Dependent Halogenase Genetic Analysis-The $\mathrm{FADH}_{2}$-dependent} halogenases are different from the haloperoxidases in that they require oxygen instead of hydrogen peroxide and are responsible for the production of most halogenated antibiotics. The $\mathrm{FADH}_{2}$-dependent halogenases also require a flavin reductase to produce $\mathrm{FADH}_{2}$ from FAD and NADH or NADPH. Some halogenases have conserved motifs near the middle of the enzyme for two tryptophan residues (WxWxIP), which reflects the enzyme's substrate specificity for tryptophan and indole derivatives. Other halogenases preferentially bind phenols and pyrroles. The $\mathrm{FADH}_{2}$-dependent halogenase primers were designed from conserved regions of six $\mathrm{FADH}_{2}$-dependent halogenases specific for phenol and pyrrole substrates in actinomycetes strains (18). These primers may help predict the biosynthetic potential of bacterial strains. 
The $\mathrm{FADH}_{2}$-dependent halogenase primers amplified halogenase gene fragments from two bacterial isolates on the red-banded acorn worm. This is a high frequency as there were only 12 actinomycetes strains on the worm. Hornung et al. screened 550 actinomycetes known to produce natural products and found 103 bacterial isolates with $\mathrm{FADH}_{2}$-dependent halogenase genes (18). Both bacterial isolates with halogenase genes were from the Firmicutes I and Firmicutes II groups, and not the Actinobacteria (Fig. 3). The halogenase sequence of isolate X36 is $71 \%$ similar to a branched-chain amino acid transport system carrier protein from B. cereus. Halogenation reactions often occur on polyketide synthase (PKS) and nonribosomal peptide synthetase (NRPS) scaffolds with substrates that are bound to carrier proteins (38). An aminoacyl-S-PCP (peptidyl carrier protein) may be relevant for the chlorination of amino acid residues of vancomycin, balhimycin, and other glycopeptide antibiotics (38). $\mathrm{FADH}_{2}$-dependent halogenases use these scaffolds in reactions. The $\mathrm{FADH}_{2}$-dependent halogenase involved in the synthesis of the antifungal pyoluterorin dichlorinates a pyrrolyl-S-carrier protein (39).

The halogenase fragment from isolate X36 is similar to amino acid transport proteins, but also shares $66-67 \%$ similarity with tryptophan halogenases in Paenibacillaceae and Bacillus strains (Fig. 11). The halogenases from Paenibacillaceae sp., Bacillus sp., and isolate $\mathrm{X} 36$ are approximately 1,000-bp in size. The halogenase from isolate X36 is closely related to the halogenase from Bacillus cereus subsp. cytotoxis, as shown in the $\mathrm{FADH}_{2}$-dependent halogenase phylogenetic tree (Fig. 12). These results are consistent with the 16S rDNA phylogenetic tree results. Isolate X36 
clustered more closely with Bacillus genera than with isolate 6 , which is related to Paenibacillus bacteria.

\section{Summary}

This study shows that 19 bacteria present on the red-banded acorn worm Ptychodera jamaicensis have bromoperoxidase genes, and two isolates have genes similar to the $\mathrm{FADH}_{2}$-dependent halogenases. According to the NCBI website, there are only eight halogenase genes in the Firmicutes phyla (40). These genes synthesize halogenation enzymes responsible for most of the halogenated antibiotics produced in bacteria, and Bacillus bacteria are the second major producer of antibiotics. With the large amount of Bacillus and Actinobacteria present in the oceanic sediment, these bacteria may be capable of producing novel halogenated products. It seems that the bacteria living on the red-banded acorn worm Ptychodera jamaicensis have the capability to produce halogenation enzymes. Furthermore, the bacterial isolate I37 is a Bacillus with a bromoperoxidase active enzyme that brominates phenol red and monochlorodimedone.

Bacteria living on acorn worms appear to contribute to the production of bromophenols present on the worms. These compounds may act as antibiotics that ward off gram-negative bacteria from settling on the worm and within its burrows, which may explain why only gram-positive bacteria were isolated from the red-banded acorn worm. Brominated compounds produced by algae can disrupt the growth of gram-negative bacterial biofilms (41). The organohalogens may also aid the acorn worm as chemical 
deterrents, and chemical substrates in bioluminescent reactions (42, 43-45). There appears to be a mutualistic relationship between marine acorn worms and bacteria. There are many examples of bacteria forming commensal and mutualistic relationships with marine worms. For example, bacteria in the integument of the marine worm Urechis caupo may metabolize toxic hydrogen sulfide produced in the hypoxic worm burrows at low tide (46). The hydrothermal vent worm Riftia pachyptila, also uses commensal bacteria to digest noxious materials it ingests (47).

The ocean is a logical place to search for new bacteria and halogenated products. The Proteobacteria, Bacteroidetes, Fusobacteria, Actinobacteria, and Firmicutes are among the phyla found within the oceanic sediment, but there is much bacterial diversity that remains to be discovered (48). Gontang, Fenical, and Jensen isolated bacteria from intertidal sediments to depths of 500 meters and found that $37.2 \%$ of operational taxonomic units likely represent new taxa and the remainder belonged to the Actinobacteria and Firmicutes phyla (49). These bacteria are a significant source of natural products and may be found living in symbiotic relationships with other marine organisms.

This study is ongoing and 35 bacterial isolates remain to be screened for bromoperoxidase active proteins. Future research includes conducting mass spectrophotometric scans of the culture supernatant of isolate X36 and I37 for bromophenols and other halogenated organics. The bromoperoxidase active isolate from I37 will be assayed for cytochrome c(6) activity and the protein sequenced for identification. SDS-PAGE gels can show if the bromoperoxidase active enzyme of 
isolate $\mathrm{I} 37$ is $67 \mathrm{kDa}$, or if it is composed of monomer polypeptide subunits. Isolation and characterization of these enzymes have the potential to support the large scale production of future antibiotics, antitumor agents, and catalysts in green chemistry processes. 


\section{References}

1. Gribble, G.W. (2003) Chemosphere 52, 289-297

2. Häggblom, M.M, and Bossert, I.D. (2003) Dehalogenation: microbial processes and environmental applications, Kluwer Academic Publishers, Boston, MA

3. Podgorsek, A., Zupan, M., and Iskra, J. (2009) Angew. Chem., Int. Ed. 48, $8424-8450$

4. Hofmann, B., Tölzer, S., Pelletier, I., Altenbuchner, J., van Pée, K.H., and Hecht, H.J. (1998) J. Mol. Biol. 279, 889-900

5. Higa, T., and Scheufer, D.J. (1977) Mar. Nat. Prod. Chem. 35, 35-43

6. Fielman, K.T., and Targett, N.M. (1995) Mar. Ecol. Prog. Ser. 116, 125-136

7. Winter, J.M., Moffitt, M.C., Zazopoulos, E., McAlpine, J.B., Dorrestein, P.C., and Moore, B.S. (2007) J. Biol. Chem. 282, 16362-16368

8. Dairi, T., Nakano, T., Aisaka, K., Katsumata, R., and Hasegawa, M. (1995) Biosci., Biotechnol., Biochem. 59, 1099-1106

9. Piraee, M., White, R.L., and Vining, L.C. (2004) Microbiology 150, 85-94

10. Hammer, P.E., Hill, D.S., Lam, S.T., van Pée, K.H., and Ligon, J.M. (1997) Appl. Environ. Microbiol. 63, 2147-2154

11. Keller, S., Wage, T., Hohaus, K., Hölzer, M., Eichhorn, E., and van Pée, K.H. (2000) Angew. Chem., Int. Ed. 39, 2300-2302

12. Hohaus, K., Altmann, A., Burd, W., Fischer, I., Hammer, P.E., Hill, D.S., 
Ligon, J.M., and van Pée, K.H. (1997) Angew. Chem. Int. Ed. Engl. 36, 2012-2013

13. Nowak-Thompson, B., Chaney, N., Wing, J.S., Gould, S.J., and Loper, J.E. (1999) J. Bacteriol. 181, 2166-2174

14. Pelzer, S., Süßmuth, R., Heckmann, D., Recktenwald, J., Huber, P., Jung, G., and Wohlleben, W. (1999) Antimicrob. Agents Chemother. 43, 15651573

15. Zehner, S., Kotzsch, A., Bister, B., Süssmuth, R.D., Méndez, C., Salas, J.A., and van Pée, K.H. (2005) Chem. Biol. 12, 445-452

16. Seibold, C., Schnerr, H., Rumpf, J., Kunzendorf, A., Hatscher, C., Wage, T., Ernyei, A.J., Dong, C., Naismith, J.H., and van Pée, K.H. (2006) Biocatal. Biotransform. 24, 401-408

17. Eustáquio, A., Gust, B., Luft, T., Li, S., Chater, K.F., and Heide, L. (2003) Chem. Biol. 10, 279-288

18. Hornung, A., Bertazzo, M., Dziarnowski, A., Schneider, K., Welzel, K., Wohlert, S.E., Holzenkämpfer, M., Nicholson, G.J., Bechthold, A., Süssmuth, R.D., Vente, A., and Pelzer, S. (2007) ChemBioChem. 8, 757-766

19. Weisburg, W.G., Barns, S.M., Pelletier, D.A., and Lane, D.J. (1991) J. Bacteriol. 173, 697-703

20. Altschul, S.F., Gish, W., Miller, W., Myers, E.W., and Lipman, D.J. (1990) J. Mol. Biol. 215, 403-410

21. Larkin, M.A., Blackshields, G., Brown, N.P., Chenna, R., McGettigan, P.A., McWilliam, H., Valentin, F., Wallace, I.M., Wilm, A., Lopez, R., Thompson, J.D., Gibson, T.J., and Higgins, D.G. (2007) Bioinformatics, 23, 2947-2948 
22. Goujon, M., McWilliam, H., Li, W., Valentin, F., Squizzato, S., Paern, J., and Lopez, R. (2010) Nucleic Acids Res. 38, W695-9

23. Tamura, K., Dudley, J., Nei, M., and Kumar, S. (2007) Mol. Biol. Evol. 24, 1596-1599

24. Neidelman, S.L., and Geigert, J. (1987) Endeavour 11, 5-15

25. Felsenstein, J. (1985) Evolution 39, 783-791

26. Roth, V. (2006) Retrieved from http://www.doubling-time.com/compute.php

27. Bérdy, J. (2005) J. Antibiot. 58, 1-26

28. White, J.M., and Torres, M.S. (2009) Defensive mutualism in microbial symbiosis, CRC Press, Boca Raton, FL

29. Rainey, F.A., Ward-Rainey, N., Kroppenstedt, R.M., and Stackebrandt, E. (1996) Int. J. Syst. Bacteriol. 46, 1088-1092

30. Rasko, D.A., Altherr, M.R., Han, C.S., and Ravel J. (2005) FEMS Microbiol. Rev. 2, 303-329

31. Pelletier, I., Altenbuchner, J, and Mattes, R. (1995) Biochim. Biophys. Acta 1250, 149-157

32. van Pée, K.H., and Lingens, F. (1985) J. Bacteriol. 161, 1171-1175

33. Knoch, M., van Pée, K.H., Vining, L.C., and Lingens, F. (1989) J. Gen. Microbiol. 135, 2493-2502 
34. Kuusk, H., Björklund, M., and Rydström, J. (2001) Enzyme Microb. Technol. 28, 617-624

35. Herut, B., Shoham-Frider, E., Kress, N., and Fiedler, U. (1998) Mar. Pollut. Bull. 36, 994-1003

36. Osipiuk, J., Gu, M., Stam, J., Anderson, W.F., and Joachimiak, A. (2008) Retrieved from http://www.ncbi.nlm.nih.gov/Structure/mmdb/mmdbsrv.cgi?uid=68903

37. Wagner, C., Molitor, I.M., and König, G.M. (2008) Phytochemistry 2, $323-332$

38. Puk, O., Bischoff, D., Kittel, C., Pelzer, S., Weist, S., Stegmann, E., Süssmuth, R.D., and Wohlleben, W. (2004) J. Bacteriol. 186, 6093-6100

39. Dorrestein, P.C., Yeh, Ellen, Garneau-Tsodikova, S., Kelleher, N.L., and Walsh, C.T. (2005) Proc. Natl. Acad. Sci. U.S.A. 102, 13843-13848

40. Retrieved October 13, 2011 http://www.ncbi.nlm.nih.gov/nuccore

41. Manefield, M., de Nys, R., Kumar, N., Read, R., Givskov, M., Steinberg, P., and Kjelleberg, S. (1999) Microbiology 145, 283-291

42. Woodin, S.A., Lindsay, S.M., and Lincoln, D.E. (1997) Mar. Ecol. Prog. Ser. 157, 303-306

43. Cormier, M.J., and Dure, L.S. (1963) J. Biol. Chem. 238, 785-789

44. Ashworth, R.B., and Cormier, M.J. (1967) Science 155, 1558-1559 
45. Kanakubo, A., Koga, K., Isobe, M., and Yoza, K. (2005) Luminescence 20, $397-400$

46. Menon, J.G., and Arp, A.J. (1993) Biol. Bull. 185, 440-454

47. Charton, B. (2008) The facts on file dictionary of marine science Infobase Publishers, New York, NY

48. Köpke, B., Wilms, R., Engelen, B., Cypionka, H., and Sass, H. (2005) Appl. Environ. Microbiol. 71, 7819-7830

49. Gontang, E.A., Fenical W., \& Jensen, P.R. (2007) Appl. Environ. Microbiol. 73, 3272-3282 